\title{
Emerging complexity of the HuD/ELAVI4 gene; implications for neuronal development, function, and dysfunction
}

\author{
LUCAS M. BRONICKI and BERNARD J. JASMIN ${ }^{\mathbf{1}}$ \\ Department of Cellular and Molecular Medicine, Faculty of Medicine, University of Ottawa, Ottawa, Ontario, Canada K1H 8M5
}

\begin{abstract}
Precise control of messenger RNA (mRNA) processing and abundance are increasingly being recognized as critical for proper spatiotemporal gene expression, particularly in neurons. These regulatory events are governed by a large number of transacting factors found in neurons, most notably RNA-binding proteins (RBPs) and micro-RNAs (miRs), which bind to specific cisacting elements or structures within mRNAs. Through this binding mechanism, trans-acting factors, particularly RBPs, control all aspects of mRNA metabolism, ranging from altering the transcription rate to mediating mRNA degradation. In this context the best-characterized neuronal RBP, the Hu/ELAVI family member HuD, is emerging as a key component in multiple regulatory processes-including pre-mRNA processing, mRNA stability, and translation-governing the fate of a substantial amount of neuronal mRNAs. Through its ability to regulate mRNA metabolism of diverse groups of functionally similar genes, HuD plays important roles in neuronal development and function. Furthermore, compelling evidence indicates supplementary roles for $\mathrm{HuD}$ in neuronal plasticity, in particular, recovery from axonal injury, learning and memory, and multiple neurological diseases. The purpose of this review is to provide a detailed overview of the current knowledge surrounding the expression and roles of $\mathrm{HuD}$ in the nervous system. Additionally, we outline the present understanding of the molecular mechanisms presiding over the localization, abundance, and function of HuD in neurons.
\end{abstract}

Keywords: HuD/ELAVI4; RNA-binding protein; mRNA metabolism; post-transcriptional regulation

\section{INTRODUCTION}

The flow of genetic information from DNA to protein requires numerous stages of intricate control, with a myriad of regulatory events occurring between transcription and translation. These regulatory events are orchestrated by trans-acting factors, a group of regulatory molecules comprising RNA-binding proteins (RBPs) and multiple classes of noncoding RNAs (ncRNAs), that aggregate onto mRNAs and form messenger ribonucleoprotein (mRNP) complexes (Lukong et al. 2008; Carninci 2010). The past two decades have seen tremendous advances in the discovery of novel types of trans-acting factors and provided a greater understanding of their diverse and vital roles in mRNA metabolism. By binding to cis-acting elements and/or structures in mRNAs, trans-acting factors control a broad spectrum of processes that range from alternative splicing and polyadenylation in the nucleus to localization, stabilization, and translation in the cytoplasm (Carmody and Wente 2009; Licatalosi and Darnell 2010; Vazquez-Pianzola and Suter 2012; Wu and Brewer 2012). Some trans-acting factors, in particular, RBPs, have been shown to transition mRNAs encoding proteins with similar functions through different

\footnotetext{
${ }^{1}$ Corresponding author

E-mail jasmin@uottawa.ca

Article is online at http://www.rnajournal.org/cgi/doi/10.1261/rna. 039164.113 .
}

post-transcriptional stages, thereby effectively coupling distinct regulatory events during mRNA metabolism (Dahan et al. 2011). The coordination of groups of mRNAs along successive processing and regulatory events formed the premise of the RNA operon theory, which helps to clarify the organization and dynamics of post-transcriptional networks (Keene 2007). These networks, collectively known as the ribonome, confer numerous benefits to cells including increasing protein diversity from a fixed number of genes, accurate spatial and temporal gene expression, and rapid modification of protein levels (Mansfield and Keene 2009).

The advantages convened by post-transcriptional regulation are particularly necessary in neurons since these cells contain complex cellular architecture due to extensive neurite branching. In addition to playing critical roles in neuronal development, maintenance, and function, the importance of these regulatory events is further highlighted by the growing number of diseases associated with mutations of certain mRNAs or dysregulation of RBPs or ncRNAs, notably small ncRNAs termed micro-RNAs (miRs), that associate with them (Lukong et al. 2008; Cooper et al. 2009; Esteller 2011; Im and Kenny 2012). For example, defects affecting the normal expression of mRNAs and/or function of RBPs are central in the etiology and pathogenesis of a broad spectrum of neuronal diseases, including the neurodegenerative disorders fragile $\mathrm{X}$ syndrome, fragile $\mathrm{X}$ tremor ataxia syndrome 
(Li and Jin 2012), spinal muscular atrophy (SMA) (Fallini et al. 2012b), Huntington's disease (Krzyzosiak et al. 2012), and amyotrophic lateral sclerosis (ALS) (Fiesel and Kahle 2011; Strong and Volkening 2011).

The nervous system encompasses an extensive amount of RBPs, many of which are critical for neuronal development. In support of this idea, one genome-wide screen found that $85 \%$ of the 380 RBPs examined were expressed in the embryonic (E13.5) and early postnatal (P0) mouse brain (McKee et al. 2005). Most notable are the well-described RBPs that regulate various stages of mRNA metabolism and are important for proper neuronal differentiation and/or function, such as butyrate-response factor 1 (BRF1) (Sanduja et al. 2011), neuro-oncologic ventral antigens 1/2 (NOVA 1/2) (Darnell 2006), A $+\mathrm{U}$ binding factor 1 (AUF1) (Gratacos and Brewer 2010), tristetraprolin (TTP) (Sanduja et al. 2011), K homology splicing regulatory protein (KSRP) (Briata et al. 2012), and $\mathrm{Hu}$ /embryonic lethal abnormal vision-like (ELAVl) (Table 1; Pascale et al. 2008). The majority of RBPs can be clustered according to their similar molecular functions, such as those belonging to the translation and turnover regulatory (TTR)-RBP group. Although not limited to these functions, TTR-RBPs are involved in stabilizing/destabilizing mRNAs and promoting/ inhibiting translation, and comprise various members, including TTP, KSRP, AUF, and Hu/ELAVl proteins (Table 1; Pullmann et al. 2007). Among all the RBPs expressed in neurons, the best characterized is the predominantly neuronspecific $\mathrm{Hu}$ member $\mathrm{HuD}$. This review will focus on the multifunctional roles and diverse regulatory events controlling the expression of $\mathrm{HuD}$ in neurons.
TABLE 1. Select AU-rich element targeting RNA-binding proteins in neurons and their effects on mRNA metabolism

RNA-binding protein Effect on mRNA

HuB/ELAVI2, HuC/ELAVI3, $\mathrm{HuD/ELAVI} 4$

HuR/ELAVI1

$\mathrm{AU}$-rich element binding factor 1 (AUF1; p37, p40, $\mathrm{p} 42$, and $\mathrm{p} 45) / \mathrm{hnRNPD}$

$\mathrm{K}$ homology-type splicing regulatory protein (KSRP)

Tristetraprolin (TTP)

Butyrate-response factor-1 (BRF1)

\section{TINO/Mex3D/RKHD1}

Polyadenylate-binding proteininteracting protein 2 (PAIP2)

CUG-binding protein 1 (CUG-BP1)

CUG-BP2 Local transcription rate enhancement (Zhou et al. 2011) Alternative splicing (Zhu et al. 2006, 2008) Alternative polyadenylation (Zhu et al. 2006) Nuclear export (Kasashima et al. 1999) Stabilization (Jain et al. 1997; Anderson et al. 2000; Mobarak et al. 2000)

Cytoplasmic transportation (Aronov et al. 2002)

Translation repression (Kullmann et al. 2002)

Translation enhancement (Antic et al. 1999; Kullmann et al. 2002; Fukao et al. 2009)

Local transcription rate enhancement (Zhou et al. 2011)

Alternative splicing (Izquierdo 2008)

Alternative polyadenylation (Zhu et al. 2006)

Nuclear export (Fan and Steitz 1998)

Stabilization (Fan and Steitz 1998; Levy et al. 1998; Peng et al. 1998)

Destabilization (Kim et al. 2009)

Translation repression (Kullmann et al. 2002)

Translation enhancement (Mazan-Mamczarz et al. 2003; Meng et al. 2005)

Mostly destabilization (Brewer and Ross 1989; Brewer 1991; Zhang et al. 1993)

Translation enhancement (Liao et al. 2007)

Transcription enhancement (Davis-Smyth et al. 1996)

Alternative splicing (Min et al. 1997)

Destabilization (Chen et al. 2001; Gherzi et al. 2004)

Cytoplasmic transport (Snee et al. 2002)

Transcription repression (Liang et al. 2009; Schichl et al. 2009)

Destabilization (Carballo et al. 1998)

Translation repression (Pfeiffer and Brooks 2012; Qi et al. 2012; Tiedje et al. 2012)

3' End processing inhibition (Desroches-Castan et al. 2011)

Destabilization (Stoecklin et al. 2002)

Destabilization (Donnini et al. 2004)

Stabilization (Onesto et al. 2004)

Translation repression (Khaleghpour et al. 2001)

Alternative splicing (Philips et al. 1998)

Destabilization (Moraes et al. 2006)

Translation enhancement (Timchenko et al. 1999)

Alternative splicing (Zhang et al. 2002)

RNA editing (Anant et al. 2001)

Stabilization (Mukhopadhyay et al. 2003)

Translation repression (Mukhopadhyay et al. 2003)

Nucleolin Transcription repression (Yang et al. 1994)

Stabilization (Chen et al. 2000)

Destabilization (Zaidi and Malter 1995)

Translation repression (Takagi et al. 2005)

Translation enhancement (Fahling et al. 2005)

\section{THE HUD GENE, mRNA, AND PROTEIN}

The name of $\mathrm{Hu} / \mathrm{ELAVl}$ genes originated from the first initials $\mathrm{(Hu})$ of the patient in which they were identified and the close relation of these genes to the Drosophila embryonic lethal abnormal vision (elav) gene (Graus et al. 1987; Okano and Darnell 1997). In addition, Hu genes are also closely related to the Drosophila sex lethal (sxl), found in neurons (fne), and
RNA-binding protein 9 (rbp9) genes. These four Drosophila genes encode RBPs that display similar structures and overlapping functions in neurons to $\mathrm{HuD}$ (Bell et al. 1988; Robinow et al. 1988; Kim and Baker 1993; Samson and Chalvet 2003; Colombrita et al. 2013). In mammals, Hu proteins were first discovered as antigens targeted by auto-antibodies in patients with the neurological syndrome paraneoplastic encephalo- 
myelitis and sensory neuropathy (PEM/SN) (Dalmau et al. 1990, 1992). This syndrome arises in a small subset of patients when the ectopic expression of $\mathrm{Hu}$ proteins in certain types of cancers, typically small cell lung carcinomas (SCLCs), provokes an autoimmune attack on the nervous system.

Out of the four Hu members, HuD was the first to be cloned and characterized, followed by HuC/ELAVl3, HuB/ELAVl2, and HuR/ELAVl1 (Szabo et al. 1991; King et al. 1994; Sakai et al. 1994; Ma et al. 1996). The expression of three Hu members- $\mathrm{HuB}, \mathrm{HuC}$ and $\mathrm{HuD}-$ is predominantly restricted to neurons (nELAVs), while HuR is found in most cell types (Szabo et al. 1991; King et al. 1994; Good 1995; Ma et al. 1996; Okano and Darnell 1997). In addition, nELAVs share a higher degree of amino acid sequence identity $(>80 \%)$ with each other compared to HuR (72.5\%-73.6\%) (Okano and Darnell 1997). Despite the high degree of sequence identity between nELAVs, variation of amino acid composition in key regions, particularly the $\mathrm{N}$-terminal and linker regions (see below), and spatiotemporal expression suggest that $\mathrm{HuD}$ carries out some unique roles and is subjected to partially distinct regulation (Okano and Darnell 1997; Clayton et al. 1998; Hambardzumyan et al. 2009).

Overall, the $H u D$ gene is well conserved among higher vertebrates and is located on chromosome 1 in humans and chromosome 4 in mice (Fig. 1A). The human and mouse $H u D$ gene spans $\sim 146 \mathrm{~kb}$ of DNA and is divided into seven coding exons (E2 to E8) that encompass $\sim 44 \mathrm{~kb}$ of DNA (Sekido et al. 1994; Inman et al. 1998). For several years, the $5^{\prime}$ region of $H u D$ was thought to contain three presumably untranslated exon 1 variants (termed E1a, E1b, and E1c) that are alternatively spliced to the $5^{\prime}$ end of exon 2 (Inman et al. 1998). Recent findings in our laboratory, however, have identified the expression of five additional $\mathrm{HuD}$ E1 variants, resulting in a total of eight (Fig. 1A,B; Bronicki et al. 2012). We also found that most E1 variants house an in-frame methionine codon (with the exception of $\mathrm{E} \mathrm{a}^{4}$, since it harbors two stop codons downstream from the AUG), suggesting that they may encode alternate $\mathrm{HuD} \mathrm{N}$ termini.

In addition to the $5^{\prime}$ end, $H u D$ pre-mRNA is subjected to alternative splicing of exons (E) 6 and 7, resulting in three additional transcript isoforms $\left(H u D, H u D_{\text {mex }}\right.$, and $\left.H u D_{\text {pro }}\right)$ (Fig. 1B,C), two of which are predominantly expressed in the postnatal mouse brain $\left(H u D\right.$ and $\left.H u D_{\text {pro }}\right)$ (Inman et al. 1998). The combinatorial complexity of $\mathrm{HuD}$ alternative $5^{\prime}$ and $3^{\prime}$ exons may produce up to 24 different mRNA variants. The HuD protein, like all Hu members, has a molecular weight of $\sim 40 \mathrm{kDa}$ and contains three RNA recognition motifs (RRMs) with a linker region separating the second and third RRM (Fig. 1C; Good 1995; Liu et al. 1995; Okano and Darnell 1997). The RRM is the most abundant (found in up to $1 \%$ of human genes) and well-characterized RNA-binding domain, composed of $\sim 90$ amino acids (Clery et al. 2008). In the $\mathrm{HuD}$ gene locus, $\mathrm{E} 2$ and $\mathrm{E} 3, \mathrm{E} 4$ and $\mathrm{E} 5$, and $\mathrm{E} 8$ encode the three RRMs, respectively, whereas the alternatively spliced E6

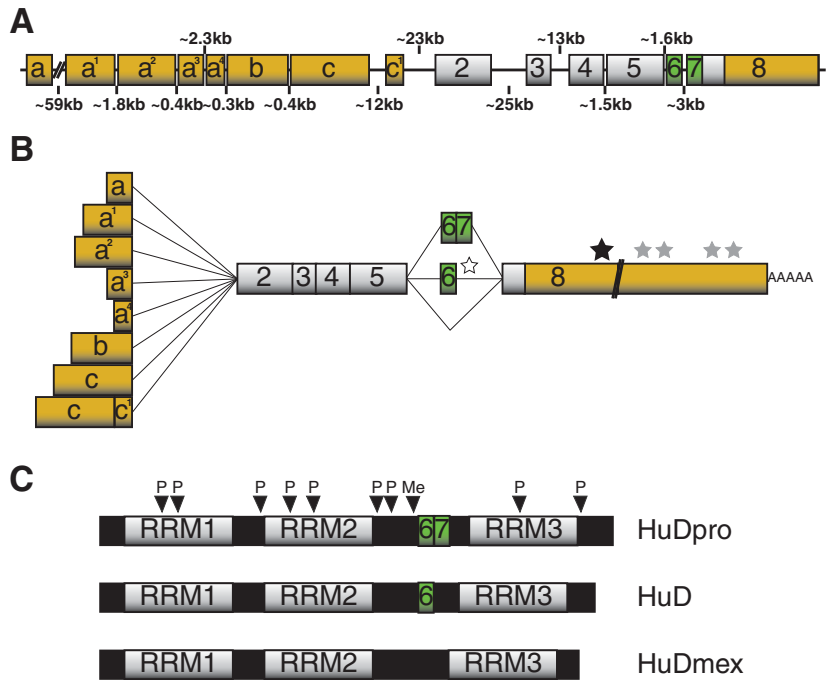

FIGURE 1. Organization of the mouse $H u D$ gene, mRNA, and protein. (A) Mouse $H u D$ gene organization with noncoding exons depicted as orange rectangles, coding exons as gray and green rectangles, and introns as black lines. $(B)$ Alternative splicing/processing of $H u D$ premRNA produces different $\mathrm{HuD}$ isoforms. $5^{\prime} / 3^{\prime}$ UTRs and coding exons are represented by orange and gray rectangles, respectively. Green rectangles denote alternatively spliced exons near the $3^{\prime}$ end of the gene. Also shown are the approximate locations of the Hu/ELAVl (white star), miR-375 (black star), and putative ARE (gray stars) binding sites. (C) The three major $\mathrm{HuD}$ protein variants found in neurons with position of RRMs (gray) and amino acid extensions in the linker region (green) shown. "P" and "Me" indicate approximate locations of serine/threonine and arginine residues that are subjected to phosphorylation by PKC and methylation by CARM1, respectively.

and E7 encode the linker region (Inman et al. 1998). The HuD linker region contains multiple residues that are post-translationally modified and houses the nuclear export (NES) and putative nuclear localization (NLS) signals (Kasashima et al. 1999).

$\mathrm{HuD}$ utilizes its RRMs to recognize and bind specific target mRNAs. Deletion and mutational analysis of the $\mathrm{HuD}$ protein revealed that the first two RRMs bind to the cis-acting elements, typically in the $3^{\prime}$ UTR, while the third RRM interacts with the poly (A) tail of transcripts and stabilizes the RBPmRNA complex (Chung et al. 1996, 1997; Ma et al. 1997; Ross et al. 1997; Anderson et al. 2000; Park et al. 2000; Wang and Tanaka Hall 2001; Beckel-Mitchener et al. 2002). Binding to the poly(A) tail seems to depend on the tail length, since results from in vitro binding assays demonstrated that the longer the poly $(\mathrm{A})$ tail, the higher the affinity of $\mathrm{Hu}$ protein binding to its target mRNA (Beckel-Mitchener et al. 2002). Another function of the third RRM of HuD involves interacting with other proteins, including homo- and hetero-multimerizing with $\mathrm{Hu}$ members (Kasashima et al. 2002). Both the Drosophila ELAV and other mammalian $\mathrm{Hu}$ proteins have also been shown to form homo-multimers on target mRNAs, suggesting that complex formation is an evolutionarily conserved mechanism necessary for efficient function of $\mathrm{Hu}$ members (Levine et al. 1993; Gao and Keene 1996; Kasashima et al. 
2002; Devaux et al. 2006; Fialcowitz-White et al. 2007; Toba and White 2008).

\section{TEMPORAL AND SPATIAL EXPRESSION OF HuD}

Converging findings suggest that $\mathrm{HuD}$ is one of the earliest markers of the neuronal phenotype (Good 1995; Okano and Darnell 1997; Wakamatsu and Weston 1997; Hambardzumyan et al. 2009). Multiple laboratories have demonstrated via Northern blots and quantitative RT-PCR that $H u D$ mRNA levels are detectable by day 10 of mouse and rat embryonic brain development, peak at E16, and slowly decline until birth (Clayton et al. 1998; Hambardzumyan et al. 2009; Abdelmohsen et al. 2010). This temporal pattern of mRNA expression is similar to that of $\mathrm{HuB}$ and $\mathrm{HuC}$, although there is some evidence that the relative abundance of each nELAV member varies at different time points of development (Good 1995; Okano and Darnell 1997; Hambardzumyan et al. 2009).

In situ hybridization analyses of $n E L A V$ expression in the mouse brain at day 14 of embryogenesis (E14) have revealed that the spatial expression of $H u D$ mRNA is also partially unique compared to $H u B$ and $H u C$ (Okano and Darnell 1997), thus further supporting the notion that $\mathrm{HuD}$ is not completely functionally redundant. In the developing mouse and rat cerebral cortex, $H u D$ mRNA is present in proliferating neuronal stem/progenitor cells in the ventricular zone, neuroblasts migrating in the intermediate zones, and terminally differentiating neurons in the cortical plate (Okano and Darnell 1997; Clayton et al. 1998). HuD transcripts are also present in several regions of the developing hippocampal formation, olfactory bulb, retina and spinal cord, such as sensory and motor neurons (Okano and Darnell 1997; Clayton et al. 1998; Bronicki et al. 2012). In the adult mouse and rodent nervous system, expression of $H u D$ mRNA is mostly restricted to specific neuronal populations, including large pyramidal-like neurons in layer $\mathrm{V}$ of the neocortex and cerebellar cortex (Purkinje cells), the four Cornu Amonis (CA1-4) regions of the hippocampus, dorsal root ganglia, and motor neurons in the spinal cord, mitral cells in the olfactory bulb, ganglion and internal plexiform layers in the retina, and enteric nervous system neurons (Okano and Darnell 1997; Clayton et al. 1998; D’Autreaux et al. 2011).

At the subcellular level, $\mathrm{HuD}$ is predominantly expressed in the cytoplasm, with minor levels detected in the nucleus (Kasashima et al. 1999). In developing neurons, HuD is found in growth cones of extending neurites, while in mature neurons it is present in axons and dendrites, including at the pre- and post-neurite terminals, respectively (Aranda-Abreu et al. 1999; Aronov et al. 2002). Closer inspection of intraneuronal compartments revealed that $\mathrm{HuD}$ is localized to granules, along with other proteins, such as kinesin-like protein (KIF3A) and survival of motoneuron (SMN), within the cytoplasm and neurites (Aronov et al. 2002; Smith et al. 2004; Tiruchinapalli et al. 2008a,b; Hubers et al. 2010; Akten et al.
2011; Fallini et al. 2012b). In addition to being expressed in various neuronal subpopulations in the CNS and PNS, quantitative RT-PCR and Western blot analysis revealed relatively minor, although significant, HuD mRNA and protein levels in several nonneuronal tissues including lung, testes, liver, pituitary gland, pancreatic $\beta$ cells, and fiber cells of the lens (Abdelmohsen et al. 2010; Bitel et al. 2010; Lee et al. 2012). These recent findings indicate that, in parallel to its key functions in neurons, HuD likely plays important roles in several other nonneuronal cell types.

\section{Cis-ELEMENT AND TARGET mRNAs OF HuD}

The most extensively studied HuD-targeted cis-acting elements are adenosine/uridine (A/U)-rich elements (AREs) commonly found in the $3^{\prime}$ UTR of almost $10 \%$ of cellular mRNAs (Halees et al. 2008). AREs usually range from 50 to $150 \mathrm{nt}$ in size and, as their name indicates, consist of A- and $\mathrm{U}$-rich stretches. These motifs vary considerably in sequence, and for simplification, they are categorized into three major classes; class I contains one to three AUUUA pentamers in a U-rich context, class II includes overlapping UUAUUUAUU nonamers, and class III consists of U-rich sequences without AUUUA pentamers (Bakheet et al. 2003, 2006). ARE motifs are typically found in short-lived transcripts encoding proteins with diverse functions such as cellular proliferation, differentiation, transcription, RNA metabolism, inflammation, and stress-response (Bakheet et al. 2006; Khabar 2010). These elements affect the stability of mRNAs by serving as target sites for ARE-binding RBP(s), also known as AU-binding proteins (AUBPs). Out of the roughly 20 currently known AUBPs, the majority are expressed in neurons and promote mRNA decay including, for example, AUF1, TTP, and KSRP (Table 1; Wu and Brewer 2012). Nevertheless, there are a few known AUBPs that enhance mRNA stability, with $\mathrm{Hu}$ proteins being the most notable (Brennan and Steitz 2001; Hinman and Lou 2008; Pascale et al. 2008).

The crystal structure of HuD bound to $c$-fos or tumor necrosis factor a (TNFa) mRNAs illustrates that specific residues within its first two RRMs preferentially bind the pyrimidine-rich $\mathrm{X}-\mathrm{U} / \mathrm{C}-\mathrm{U}-\mathrm{X}-\mathrm{X}-\mathrm{U} / \mathrm{C}$ ?-U-U/C consensus sequence where the "?" denotes ambiguity whether a cytosine in this position is tolerated (Wang and Tanaka Hall 2001). This report also showed that the amino acid residues interacting with RNA nucleotides are well conserved among all $\mathrm{Hu}$ proteins and the Drosophila ELAV protein. Several studies have utilized in vitro and in vivo approaches such as RNA electrophoretic mobility shift assays (REMSAs) and RNA-immunoprecipitation (IP), respectively, to demonstrate that $\mathrm{HuD}$ binds to ARE sequences in mRNAs (Liu et al. 1995; Chung et al. 1996, 1997; Deschenes-Furry et al. 2003; Ratti et al. 2008). However, it is important to point out that the presence of an AUUUA sequence is not always sufficient for $\mathrm{HuD}$ binding, indicating that $\mathrm{HuD}$ displays preference for specific ARE motifs (Toba et al. 2002). 
Interestingly, a microarray screen of HuD-bound mRNAs found that less than half of its targets contain an ARE (Bolognani et al. 2010). Instead, the investigators identified three novel consensus motifs that are present in $\sim 80 \%$ of HuD-targeted mRNAs expressed in the mouse forebrain. The first motif consists of C- and U-rich stretches, with a prevalence of the former, and is located mostly in the $5^{\prime}$ and $3^{\prime}$ UTRs of mRNAs. The second and third motifs are U-rich with interspersed guanines $(G)$ or adenosines (A), respectively. These latter two motifs are predominantly found in the $3^{\prime}$ UTR and occasionally in the 5' UTR and coding regions of mRNAs. Recent high-throughput analyses, using variations of cross-linking and immunoprecipitation (CLIP) such as Photoactivatable-Ribonucleoside-Enhanced CLIP (PAR-CLIP) and individual-nucleotide resolution CLIP (iCLIP), of HuR and nELAV target mRNAs corroborate these findings by demonstrating that all four Hu proteins preferentially bind U-rich sequences interspersed with Gs or As (Lebedeva et al. 2011; Mukherjee et al. 2011; Uren et al. 2011; Ince-Dunn et al. 2012). These studies also found that Hu binding sites were mostly located in $3^{\prime}$ UTRs of mRNAs, with a significant portion in introns and relatively few in $5^{\prime}$ UTRs. In terms of $\mathrm{HuD}$, the various types of cis-acting motifs that it targets are found in mRNAs encoding proteins with diverse functions in neurons ranging from cell cycle arrest to synapse formation (Bolognani et al. 2010).

Evidence that Hu proteins bind AREs originated from a study demonstrating preferential binding of $\mathrm{HuB}$ to $\mathrm{A} / \mathrm{GUUU}$ $\mathrm{A} / \mathrm{G} / \mathrm{U}$ sequences located within the $3^{\prime}$ UTRs of mRNAs (Levine et al. 1993). This fundamental finding enabled the subsequent identification of the first target mRNA of $\mathrm{HuD}, c-f o s$, a member of the immediate early (IE) gene family of transcription factors (TFs) that encode proteins involved in cell proliferation and differentiation (Liu et al. 1995). Using REMSAs, the authors showed that $\mathrm{HuD}$ binds specifically to an ARE sequence in the $c$-fos $3^{\prime}$ UTR. Numerous other ARE-harboring transcripts, such as $N-m y c$ and $c-m y c$, were later identified as targets of $\mathrm{HuD}$ using similar in vitro approaches, indicating that $\mathrm{HuD}$ binds short-lived mRNAs whose protein product functions in cell proliferation (Liu et al. 1995; Ross et al. 1997). In addition to these transcripts, $\mathrm{HuD}$ has been shown to bind and regulate several other mRNAs in vitro and in vivo, many of which encode proteins with important functions in neuronal differentiation such as cell cycle ar- rest (p21 $1^{\text {cip1/wafl }}$ ) (Joseph et al. 1998), neuroblast proliferation (MSI-1) (Ratti et al. 2006), neuron migration (MARCKS) (Wein et al. 2003), neurite extension ([GAP-43] [Chung et al. 1997], Tau [Aranda-Abreu et al. 1999], and AChE [Cuadrado et al. 2003; Deschenes-Furry et al. 2006; Bronicki and Jasmin 2012]), synapse formation (NOVA-1) (Ratti et al. 2008), and neuronal growth and survival (NGF, BDNF, and NT-3) (Table 2; Lim and Alkon 2012).

In addition to these HuD-targeted mRNAs, three independent high-throughput studies have unravelled functionally diverse classes of genes regulated by $\mathrm{HuD}$. One of these studies purified $\mathrm{HuD}$-containing mRNP complexes from $\mathrm{HuD}$ overexpressing (HuD-Tg) adult mouse forebrains and subsequently pulled down target mRNAs with GST-HuD for microarray examination. Gene ontology analysis identified several mRNAs whose proteins are involved in regulating RNA processing, nuclear export, translation, cell-to-cell signalling, and vesicle trafficking (Bolognani et al. 2010). Of particular interest, this study also found that $\mathrm{HuD}$ binds mRNAs of several RBPs, including its own, $H u B, H u R$, Cugbp2, Musashi 2, and Staufen 2, indicating a complex regulatory network between $\mathrm{HuD}$ and other components of the ribo-

TABLE 2. Established function(s) of HuD on neuronal target mRNAs

Gene Effect of HuD on mRNA

Growth associated protein 43 (GAP-43)

p2 $1^{\text {cip } 1 / \text { waf1 }}$

Tau

p2 $7^{\text {KIP }}$

Neuroserpin

$\mathrm{N}$-myc

Myristoylated alanine-rich C

kinase substrate (MARCKS)

Acetylcholinesterase (AChE)

Musashi 1 (Msi1)

Calcitonin/CGRP

Ikaros

Neurofibromatosis (NF-1)

Neuro-oncological ventral antigen 1 (NOVA1)

LIM domain transcription factor (LMO4)

$\mathrm{HuD}$

HuR

Glutaminase (Gls1/Gls)

Nerve growth factor (NGF)

Neurotrophin 3 (NT-3)

Brain-derived growth factor (BDNF)
Stabilization (Liu et al. 1995; Chung et al. 1997; Tsai et al. 1997; Anderson et al. 2000; Mobarak et al. 2000)

Transportation into neurites (Smith et al. 2004)

Stabilization (Joseph et al. 1998; Fujiwara et al. 2006)

Stabilization (Aronov et al. 2002)

Transportation into neurites (Aranda-Abreu et al. 1999)

Translation enhancement (Aronov et al. 2002)

Translation repression (Kullmann et al. 2002)

Stabilization (Cuadrado et al. 2002)

Stabilization (Manohar et al. 2002)

Stabilization (Wein et al. 2003)

Stabilization (Deschenes-Furry et al. 2003)

Stabilization (Ratti et al. 2006)

Alternative splicing (exon exclusion) (Zhu et al. 2006)

Alternative polyadenylation (Zhu et al. 2006)

Alternative splicing (Bellavia et al. 2007)

Alternative splicing (exon exclusion) (Zhu et al. 2008)

Local transcription rate enhancement (Zhou et al. 2011)

Stabilization (Ratti et al. 2008)

Translation enhancement (Ratti et al. 2008)

Stabilization (Chen et al. 2007)

Alternative splicing (exon inclusion) (Wang et al. 2010)

Alternative polyadenylation (Mansfield and Keene 2011)

Alternative splicing (Ince-Dunn et al. 2012)

Stabilization (Ince-Dunn et al. 2012)

Translation enhancement (Ince-Dunn et al. 2012)

Stabilization (Lim and Alkon 2012)

Stabilization (Lim and Alkon 2012)

Stabilization (Lim and Alkon 2012) 
nome (Pullmann et al. 2007; Mansfield and Keene 2009; Bolognani et al. 2010). A second study also employed a microarray approach to determine $\mathrm{HuD}$-targeted mRNAs in dentate granule cells of HuD-Tg mice (Perrone-Bizzozero et al. 2011). The authors found that the data set is mostly enriched in mRNAs encoding proteins involved in neuronal development and axogenesis, such as Notch3 and Neurog2 (PerroneBizzozero et al. 2011). Last, a recent study used CLIP and microarray technologies to reveal that nELAVs regulate multiple transcripts, some of which encode components of the amino acid glutamate biosynthetic pathway, such as glutaminase 1, which indicates that an important function of nELAVs is to control neuronal activity (Ince-Dunn et al. 2012).

\section{MULTILEVEL CONTROL OF MRNA METABOLISM BY HuD}

\section{Alternative splicing}

Following binding to a target mRNA, HuD has been shown to control one or multiple regulatory events during the transcript's metabolism, with alternative splicing being one of the earliest. The first clues that $\mathrm{HuD}$ plays a role in alternative splicing were based on its significant homology to the Drosophila splicing factor $s x l$ (Szabo et al. 1991) and experiments demonstrating that the Drosophila ELAV protein promotes neuron-specific alternative splicing (Koushika et al. 1996). Following these seminal findings, a more direct indication that $\mathrm{HuD}$ and the other three $\mathrm{Hu}$ proteins regulate alternative splicing in mammals emerged from a study that showed $\mathrm{HuD}$ binding to both exonic and intronic regions of $N-m y c$ pre-mRNA (Lazarova et al. 1999). A few years later, a series of papers predominantly from the Hua Lou laboratory corroborated that all $\mathrm{Hu}$ proteins function as auxiliary splicing factors (Hinman and Lou 2008). Using various complementary methods, such as REMSA and UV cross-linking/IP assays, one report demonstrated that nELAVs compete with TIA-1/ TIAR RBPs for a U-rich intronic sequence in the calcitonin/ calcitonin gene-related peptide (CGRP) pre-mRNA to block inclusion of exon 4. Through this mechanism, nELAVs promote expression of the neuron-specific CGRP isoform in neurons (Zhu et al. 2006). nELAVs were also shown to interact with intronic AREs surrounding exon 23a of the neurofibromatosis type 1 (NF1) pre-mRNA to block its inclusion by inhibiting U1/U6 snRNP and U2AF auxiliary splicing factor binding to the $5^{\prime}$ and $3^{\prime}$ splice sites (SSs), respectively (Zhu et al. 2008). Furthermore, overexpression and down-regulation of $\mathrm{HuD}$ in $\mathrm{T}$-cell lines demonstrated that it mediates alternative splicing of the Ikaros gene, possibly by suppressing exon 4 inclusion (Bellavia et al. 2007; Hinman and Lou 2008). In addition to binding intronic sequences, co-IP assays revealed that $\mathrm{Hu}$ proteins interact with RNA polymerase II and histone deacetylase 2 (HDAC2) to regulate alternative splicing (Zhou et al. 2011). In vitro transcription elongation assays showed that, by blocking HDAC2 activity, histones surrounding specific exons remained hyperacetylated, which resulted in an increased RNAPII transcription rate and decreased exon inclusion at these genomic loci. Experiments with $\mathrm{HuB}$ and $\mathrm{HuC}$ deletion mutants indicated that the linker region and RRM3 are necessary for nELAV regulation of alternative splicing (Zhu et al. 2008; Zhou et al. 2011).

In contrast to this function, evidence that $\mathrm{HuD}$ and the two other nELAVs enhance exon inclusion also exists. For instance, all four Hu members were shown to promote inclusion of $\mathrm{HuD}$ exon 6 by binding to two ARE sequences in the downstream intron (Wang et al. 2010). In addition, a recent report identified intronic nELAV binding sites flanking an alternative $3^{\prime} \mathrm{SS}$ in the Gls1/Gls gene and demonstrated that nELAVs generate a longer Gls mRNA variant, indicating that they may enhance inclusion of a Gls 3' exon(s) (Ince-Dunn et al. 2012). The same report also used genome wide analysis to map the binding sites in nELAV targeted pre-mRNAs and revealed that these proteins preferentially bind introns surrounding cassette exons, especially near exon/intron splice junctions (Ince-Dunn et al. 2012). In line with previous studies, nELAVs were found to enhance exon inclusion when bound to $5^{\prime}$ SSs in the downstream intron and inhibit exon inclusion when bound to adjacent $3^{\prime}$ and $5^{\prime}$ SSs of alternative exons. Altogether, these studies clearly demonstrate that $\mathrm{HuD}$, along with the other nELAV proteins, can promote or suppress exon inclusion by interacting with (or antagonizing) splicing, transcription, and chromatin components (Fig. 2A).

\section{Alternative polyadenylation}

In addition to alternative splicing, both the Drosophila ELAV and the mammalian $\mathrm{Hu}$ proteins were demonstrated to control alternative polyadenylation specifically in neurons (Soller and White 2003). Truncation of the mouse HuB protein revealed that all three RRMs are necessary for $\mathrm{Hu}$ proteins to perform this function (Zhu et al. 2006). Employing mainly REMSAs and in vitro cleavage and polyadenylation assays, one study determined that $\mathrm{Hu}$ proteins bind U-rich sequences downstream from the exon 4 poly(A) signal in calcitonin/CGRP to block binding of cleavage stimulation factor 64 (CstF64) and cleavage-polyadenylation specificity factor (CPSF), essential components of the cleavage and polyadenylation machinery. Through this mechanism Hu proteins prevent cleavage and polyadenylation at the nonneuronal exon 4 poly(A) signal, thereby promoting the neuron-specific CGRP pathway (Zhu et al. 2006). Moreover, all four Hu proteins were recently demonstrated to differentially regulate alternative polyadenylation of $\mathrm{HuR}$ in neurons (Mansfield and Keene 2011; also see Dai et al. 2012). Mansfield and Keene showed that there are three different HuR mRNA polyadenylation variants $(1.5,2.4$, and $6.0 \mathrm{~kb})$, which differ in $3^{\prime}$ UTR length. All four Hu members were found to bind and block U-rich sequences near the 2.4 -kb polyadenylation site and thereby promote expression of the $6.0-\mathrm{kb}$ transcript. Since the $6.0-\mathrm{kb}$ variant is less stable and not as efficiently 


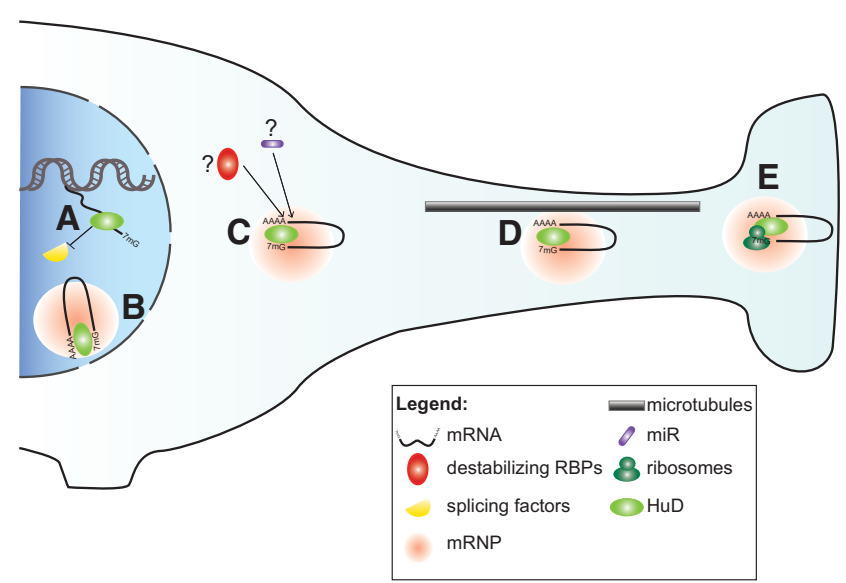

FIGURE 2. Model depicting the intracellular localizations and multiple post-transcriptional functions of $\mathrm{HuD}$. (A) In the nucleus, $\mathrm{HuD}$ regulates alternative splicing and polyadenylation by competing for specific pre-mRNA binding sites with other trans-acting factors. (B) $\mathrm{HuD}$ forms part of an mRNP complex, and it likely facilitates mRNA export into the cytoplasm. (C) In the cytoplasm, HuD and destabilizing RBPs bind competitively or cooperatively to mRNAs. HuD might also prevent binding of miRs to the mRNA or antagonize their function. Through these mechanisms, HuD increases the half-lives of mRNAs. (D) HuD transports mRNAs to different compartments of neurons, most notably neurites, along microtubules. $(E)$ At the synaptic terminal, HuD may promote or repress translation of transcripts.

translated as the $2.4-\mathrm{kb}$ transcript, the authors postulated that the reduction of HuR expression prevents HuR's ability to promote proliferation and thereby permits neurons to terminally differentiate (Mansfield and Keene 2011). The role of $\mathrm{Hu}$ proteins in controlling alternative polyadenylation is likely extended to several of their target mRNAs, given that the ELAV protein in Drosophila was found to coordinate $3^{\prime}$ UTR extension of multiple mRNAs in neuronal cells (Hilgers et al. 2012).

\section{Nucleocytoplasmic shuttling}

Another chief function of $\mathrm{HuD}$ involves shuttling of target mRNAs into the cytoplasm. As previously mentioned, $\mathrm{HuD}$ contains a NES and putative NLS located in the variable linker domain, between the second and third RRM, which permit nucleocytoplasmic shuttling of $\mathrm{HuD}$ (Fig. 2B; Kasashima et al. 1999). Overexpression of wild-type and deletion mutant $\mathrm{HuD}$ proteins revealed that cytoplasmic shuttling of $\mathrm{HuD}$ requires the NES region (Kasashima et al. 1999). Moreover, in vitro binding assays showed that the first two RRMs of $\mathrm{HuD}$ associate with the primary general mRNA export adaptor complex (TAP-p15; also known as NXF1/NXT1) in a RNA-independent manner and that this interaction may be necessary for shuttling of $\mathrm{HuD}$ (Saito et al. 2004). Further studies are necessary to establish whether TAP-p45 and/or another export pathway, such as the karyopherin CRM1, is used by $\mathrm{HuD}$ for nuclear export of mRNAs (Carmody and Wente 2009).

\section{mRNA stability}

The initial demonstration that $\mathrm{Hu}$ proteins regulate mRNA stability was based on the observation that $\mathrm{HuB}$ enhances GLUT1 mRNA half-life and, incidentally, translation (Jain et al. 1997). Following this landmark study, other reports described similar roles for HuR (Fan and Steitz 1998; Levy et al. 1998; Peng et al. 1998) and HuC/D (Anderson et al. 2000; Mobarak et al. 2000) in regulating mRNA stability. Since these initial findings, $\mathrm{HuD}$ has emerged as the best-described stabilizing RBP in neurons, as evidenced by the numerous studies outlining its role in increasing the half-lives of various neuronal transcripts (Fig. 2C). Among all of the HuD-regulated mRNAs, the most prominent is the GAP-43 mRNA, which houses a class III ARE in its 3' UTR (Chung et al. 1997; Tsai et al. 1997). HuD-dependent control of GAP-43 expression is particularly interesting because GAP- 43 plays multiple roles in neurons, including functioning as a critical component in neural development (Maier et al. 1999; Mani et al. 2001; Shen et al. 2008) and synaptic remodeling during learning and memory (Routtenberg et al. 2000). Multiple studies have shown that overexpression or down-regulation of $\mathrm{HuD}$ results in increased or decreased, respectively, GAP-43 mRNA levels and/or stability in cultured cells and the mouse nervous system (Anderson et al. 2000, 2001; Mobarak et al. 2000; Bolognani et al. 2006, 2007a). Interestingly, $\mathrm{HuD}$ is more effective at stabilizing GAP-43 mRNAs that contain a longer poly(A) tail, indicating that $\mathrm{HuD}$ binds to both the ARE and poly(A) tail to increase GAP-43 mRNA half-life (Beckel-Mitchener et al. 2002). In addition to GAP-43 transcripts, $\mathrm{HuD}$ has also been shown to promote the stability of several other ARE-containing mRNAs in neurons, such as AChE (Deschenes-Furry et al. 2003) and Nova1 (Ratti et al. 2008 ), both in vitro and in vivo (Table 2; Perrone-Bizzozero and Bird 2013). Despite mRNA stabilization being one of the better-known roles of $\mathrm{HuD}$, the molecular events behind this function are not well understood.

One likely mechanism through which $\mathrm{HuD}$ and other $\mathrm{Hu}$ members stabilize mRNAs involves antagonizing destabilizing RBPs such as AUF1 from binding to cis-acting elements (Barreau et al. 2006). Once bound to a target mRNA, destabilizing RBPs may promote deadenylation through a variety of manners such as blocking poly(A) binding protein (PABP) binding and/or recruitment of decapping, deadenylation, and exosome components ( $\mathrm{Wu}$ and Brewer 2012). Thus, it is feasible that, by binding to AREs or other motifs, $\mathrm{HuD}$ blocks access to the binding site and consequently prolongs mRNA half-life (Fig. 3). However, there is evidence indicating that this mechanism is more complex since both stabilizing and destabilizing RBPs can bind the same transcript simultaneously. Fluorescence resonance energy transfer (FRET) and biochemical techniques revealed that $\mathrm{HuR}$ interacts with AUF1, KSRP, and TIA-1 in the nucleus and cytoplasmic stress granules (David et al. 2007; David Gerecht et al. 2010). Moreover, these interactions require the presence 
A
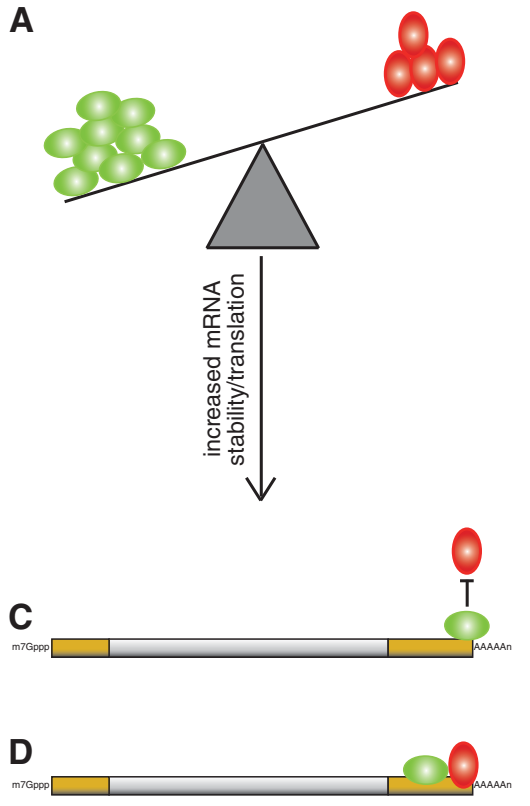

$\mathbf{E}$

FIGURE 3. Relative levels of RBPs and their cooperative and competitive binding to mRNAs controls gene expression. The relative expression of RBPs that $(A, B)$ promote (e.g., Hu/ELAVl proteins; green) or inhibit (e.g., AUF1; red) mRNA stability/translation influences gene expression. Functionally antagonistic RBPs can also bind $(C)$ competitively or $(D, E)$ cooperatively to regulate mRNA fate. Cooperative binding could potentially allow for a quicker response to extracellular cues in determining mRNA fate.

of RNA, since HuR and AUF1 were shown to simultaneously or competitively bind onto exclusive or common, respectively, cis-acting elements in the $3^{\prime}$ UTRs of $p 21^{\text {cip1/waf1 }}$, Cyclin D, TNFa, and $\beta_{2}$-adrenergic receptor mRNAs (Lal et al. 2004; David et al. 2007). Together, these findings suggest that regulation of mRNA stability, and likely other mRNA metabolism events, by Hu proteins is at least partially dependent on a balance between stabilizing and destabilizing RBPs (Fig. 3).

\section{mRNA localization and translation}

Along with promoting mRNA stability, compelling evidence supports a role for $\mathrm{HuD}$ in regulating both localization and translation of transcripts in the cytoplasm and possibly in neurites (Fig. 2D,E). For example, two target mRNAs of HuD involved in axonal outgrowth, namely GAP-43 and Tau, were found to colocalize with $\mathrm{HuD}$ protein and polysomes in growth cones during neuronal differentiation (Smith et al. 2004; Atlas et al. 2007). Co-IP and immunocytochemistry experiments revealed that $\mathrm{HuD}$ interacts with a host of mRNP components involved in transport and translation in the cytoplasm and neurites such as the motor protein KIF3A (Aronov et al. 2002), IGF-II mRNA binding protein 1 (IMP-1) (Atlas et al. 2004, 2007), survival of motor neuron (SMN) (Hubers et al. 2010; Akten et al. 2011; Fallini et al. 2011), poly(A) bind- ing protein $(\mathrm{PABP})$, translation initiation factor 4E (eEF4E) (Tiruchinapalli et al. $2008 \mathrm{~b}$ ) and the microtubule-associated component MAP1B (Fujiwara et al. 2011b). Various conditions, including $\mathrm{KCl}$ depolarization of primary hippocampal neurons, cocaine, or seizure treatment of mice and phorbol ester or bryostatin1 application to human neuroblastoma (NB) cells, result in an augmented abundance of $\mathrm{HuD}$, its redistribution to neurites, and its increased association with mRNAs and mRNP components (Pascale et al. 2005; Tiruchinapalli et al. 2008a,b). Complementary to its role in mRNA localization, evidence for the direct involvement of $\mathrm{HuD}$ in regulating translation was unveiled when Fukao and colleagues showed that $\mathrm{HuD}$ binds to eIF4A and the $\operatorname{poly}(\mathrm{A})$ tail of transcripts, via its linker region and third RRM, to enhance cap-dependent protein synthesis (Fukao et al. 2009). Moreover, this mechanism was determined to be important for $\mathrm{HuD}$ dependent neurite extension in PC12 cells.

In addition to enhancing translation, $\mathrm{HuD}$ is capable of repressing protein synthesis, as shown for $p 27$ and preproinsulin (Ins2) mRNAs (Kullmann et al. 2002; Lee et al. 2012). Even though the mechanism of translational silencing is unclear, it was demonstrated to require $\mathrm{HuD}$ binding to an internal ribosome entry site (IRES) in the $5^{\prime}$ UTR of p27 mRNA (Kullmann et al. 2002) and a short 22-nt sequence in the $5^{\prime}$ UTR of Ins 2 mRNA (Lee et al. 2012). The report by Kullman et al. suggests that inhibition of p27 translation by $\mathrm{Hu}$ proteins is an event that sustains cells in a proliferative state (Kullmann et al. 2002). On the other hand, the study by Lee et al. showed that the repression of Ins 2 translation by $\mathrm{HuD}$ is likely required to maintain insulin homeostasis (Lee et al. 2012). Taking into account these findings, it is plausible that $\mathrm{HuD}$ inhibits translation of select target mRNAs in neuronal stem/precursor cells or in response to a neuronal stress such as hypoxia. Altogether, these studies indicate that $\mathrm{HuD}$ recruits mRNAs to microtubules and may transport them to neurites to control their local translation in response to extracellular cues, particularly during neuronal development and function.

\section{MOLECULAR MECHANISMS REGULATING HuD}

The key roles of $\mathrm{HuD}$ in neuronal development and plasticity and its implications in neuronal diseases raise important questions regarding the molecular mechanisms that regulate its expression. To date, only a few studies have started to describe 
the post-translational, post-transcriptional, and transcriptional mechanisms that control the expression and function of $\mathrm{HuD}$ (Fig. 4). However, given the key functions of $\mathrm{HuD}$ in neurons, more systematic investigations of the molecular events that regulate its expression are necessary.

\section{Post-translational control of HuD expression and function}

Although some conditions, such as application of growth factors (Aranda-Abreu et al. 1999; Abdelmohsen et al. 2010), pharmacological agents (Pascale et al. 2005; Tiruchinapalli et al. 2008a,b), and cellular stress (Burry and Smith 2006), have been documented to alter the expression or function of $\mathrm{HuD}$, the molecular pathways and downstream regulators involved are only beginning to emerge. Currently, there are only three known pathways that regulate the abundance or function of $\mathrm{HuD}$ : protein kinase C (PKC) (Mobarak et al. 2000; Pascale et al. 2005; Lim and Alkon 2012); coactivatorassociated arginine methyltransferase 1 (CARM1) (Fujiwara et al. 2006; Hubers et al. 2010); and protein kinase B (PKB/ AKT) (Fujiwara et al. 2011a).

The ubiquitously expressed serine/threonine PKC family consists of at least 10 isoforms with diverse functions ranging from controlling cell proliferation to synaptic remodeling (Amadio et al. 2006). The classical PKCa isoform was shown to increase nELAV levels and provoke their nuclear export following treatment of SH-SY5Y NB cells with the PKC-activating compounds phorbol esters and bryostatin-1 (Pascale et al. 2005). Moreover, stimulation of PKCa promotes its interaction with nELAV proteins resulting in their phosphorylation at threonine residues, redistribution to the neuronal cytoskeletal and membrane fractions, and stabilization of GAP-43 mRNA. In addition, a recent study demonstrated that $\mathrm{PKC} \varepsilon$ also interacts with $\mathrm{HuD}$, and activation of both PKC isoforms by bryostatin-1 results in HuD phosphorylation on nine residues (Lim and Alkon 2012). Importantly, $\mathrm{HuD}$ is a focal downstream target of this neurite-extending pathway since nerve growth factor (NGF) or phorbol ester treatment of PC12 cells following HuD knockdown prevents neurite outgrowth (Mobarak et al. 2000).

Another pathway that has been documented to regulate $\mathrm{HuD}$ function involves the methyltransferase CARM1 (also known as protein arginine methyltransferase 4 [PRMT4]), a member of the PRMT family that performs a variety of cellular functions such as regulating transcription and RNA processing by methylating arginine residues in substrate proteins (Bedford and Clarke 2009). Using a variety of complementary techniques, including an in vitro protein methylation assay, CARM1 was demonstrated to interact with and methylate an amino acid located in the hinge region of rat $\left(\mathrm{Arg}^{236}\right)$ (Fujiwara et al. 2006) and mouse ( $\mathrm{Arg}^{248}$ ) (Hubers et al. 2010) HuD (Fig. 1C). Moreover, methylation of $\mathrm{HuD}$ decreased $p 21^{\text {cip1/waf1 }}$ mRNA stability and maintained neuronal precursor cells in a proliferative state. On the other hand, inhibition of HuD methylation or knockdown of CARM1 resulted in increased $p 21^{\text {cip1/waf } 1}$ mRNA levels, cell-cycle withdrawal, and neuronal differentiation. Surprisingly, although reduced CARM1 levels also increased GAP-43 mRNA expression, they had no effect on other known HuD-targeted mRNAs, including Tau and p27, suggesting that stabilization of these other target mRNAs requires additional posttranslational modifications of $\mathrm{HuD}$ and/or other trans-acting factors (Fujiwara et al. 2006; Hubers et al. 2010). These findings provide evidence that methylation of $\mathrm{HuD}$ by CARM1 may be a universal switch in neuronal precursors that regulates the transition from proliferation to neuronal differentiation.

A recent report found a direct link between the antagonistic effects of PKC and CARM1 on HuD function 
and cell fate (Lim and Alkon 2012). In hippocampal neurons, the study demonstrated using pathway-specific inhibitors that activated PKC isoforms interact and phosphorylate CARM1, which leads to decreased CARM1 methyltransferase activity. Furthermore, activating the classical PKC isoforms and simultaneously blocking CARM1 activity potentiates $\mathrm{HuD}$ binding to target mRNAs and hippocampal neurite extension. This study clearly illustrates that PKC activation negatively controls CARM1-mediated methylation of $\mathrm{HuD}$ to promote neuronal differentiation.

The phosphatidylinositol 3-kinase (PI3K)/AKT1 pathway was also found to regulate $\mathrm{HuD}$ function, specifically at the translational level (Fujiwara et al. 2011a). This finding is in agreement with PI3K/AKT1 being one of the prominent signalling pathways regulating translation (Roux and Topisirovic 2012). In the study by Fujiwara et al., HuD mutants were used to demonstrate direct binding of active (phosphorylated) AKT1 to a sequence in the linker region of $\mathrm{HuD}$ and that this interaction is required for $\mathrm{HuD}$-dependent neurite outgrowth (Fujiwara et al. 2011a). In addition to binding HuD, chronic (7-day) activation of AKT1 enhances $\mathrm{HuD}$ protein levels, suggesting that AKT1 also positively controls $\mathrm{HuD}$ expression (Tiruchinapalli et al. 2008a). These results indicate that AKT1 increases the abundance of $\mathrm{HuD}$ protein and interacts with the HuD-mRNA complex to promote neurite elongation, possibly through regulation of $\mathrm{HuD}$-mediated translation. Based on these findings, an emerging model suggests that, through post-translational control of $\mathrm{HuD}$ expression and function, activation of different signalling pathways can maintain neuronal precursor/stem cells in a proliferative state (CARM1) or promote neuronal differentiation (PKC and AKT1) (Fig. 4A).

\section{Post-transcriptional control of HuD expression}

Recent studies have started to decipher the molecular mechanisms controlling $H u D$ mRNA (Fig. 4B) and pre-mRNA (Fig. 4C) expression. The mammalian $H u D$ mRNA contains at least three alternate $5^{\prime}$ UTRs and a long $3^{\prime}$ UTR $(\sim 2.6 \mathrm{~kb})$, characteristics that are a strong indication of predisposition to posttranscriptional regulation. As mentioned above, previous studies, along with data from our laboratory, revealed eight $\mathrm{HuD}$ E1 variants, indicating the existence of at least eight different $5^{\prime}$ UTRs (Fig. 1A,B), with most containing an in-frame translation start site (Abe et al. 1994; Inman et al. 1998; Bronicki et al. 2012). RT-PCR analysis revealed that all eight exons are expressed in embryonic and adult mouse brain and are induced during neuronal differentiation. Moreover, our data suggest that E1c is the predominantly expressed E1 variant (Bronicki et al. 2012). Although the function of E1c and the rest of the E1 variants is unknown, it is tempting to speculate that they encode HuD 5' UTRs and/or N-terminal peptides that have important functions such as in translational control or intracellular localization (Davuluri et al. 2008).
Analysis of the Xenopus $H u D$ homolog elrD sequence illustrated that the $3^{\prime}$ UTR contains an $\sim 100$-nt stretch of nucleotides with $90 \%$ identity to the human $H u D 3^{\prime}$ UTR, implying that this fragment encompasses an important evolutionarily conserved regulatory structure and/or cis-element(s) (Good 1995). Indeed, analysis of HuD-targeted mRNAs in the mouse forebrain showed that $\mathrm{HuD}$ binds to its own transcript, although the role of this interaction remains unknown (Bolognani et al. 2010). One functional consequence of this auto-regulatory binding is presumably in controlling alternative splicing of its own pre-mRNA (see above) (Wang et al. 2010). Another possible significance of this interaction may be similar to the one found for the Drosophila ELAV homolog, which was demonstrated to negatively regulate its own transcript (Samson 1998; Borgeson and Samson 2005). This auto-regulatory mechanism is thought to occur when ELAV levels pass a certain threshold, resulting in increased ELAV binding to an AU-rich site in a noncoding $3^{\prime}$-terminal exon and production of a noncoding transcript (Borgeson and Samson 2005). Given the multifunctional roles of $\mathrm{HuD}$ on mRNA metabolism and the numerous putative ARE signatures in its $3^{\prime}$ UTR (L Bronicki and BJ Jasmin, unpubl.), it is conceivable that $\mathrm{HuD}$ also controls other regulatory events such as polyadenylation, stability, localization, and translation of its own mRNA.

Further support of the notion that trans-acting factors regulate $\mathrm{HuD}$ mRNA metabolism surfaced when miR-375 was demonstrated to target the $3^{\prime}$ UTR of $\mathrm{HuD}$ and decrease its abundance by reducing both its mRNA stability and translation (Abdelmohsen et al. 2010). Knockdown of miR-375 in cultured cells and mouse brain revealed that this microRNA prevents neurite outgrowth through negative control of $\mathrm{HuD}$ expression. Altogether, these studies stress that $\mathrm{HuD}$ transcripts are likely subjected to intricate post-transcriptional control involving RBPs and miRs.

\section{Transcriptional control of HuD expression}

Despite a few studies demonstrating direct or indirect regulation of $\mathrm{HuD}$ at post-translational, translational, and post-transcriptional levels, little was known regarding the molecular mechanisms that control transcription of this gene in neurons. As discussed above, a previous study suggested that at least three $\mathrm{HuD}$ E1 variants exist, pointing to the potential presence of multiple promoters (Inman et al. 1998). Work in our laboratory has shown that the mammalian HuD gene actually contains eight E1 variants that are well conserved among higher vertebrates, adding to the speculation that multiple promoters control HuD expression (Bronicki et al. 2012). In line with this possibility, the $5^{\prime}$ genomic region of elrD was demonstrated to contain two distinct promoters that drive neuron-specific expression of two E1 variants, E1 and E'1 (Nassar and Wegnez 2001). These variants encode transcripts exhibiting unique temporal expression during Xenopus nervous system development (Nassar 2011). Remarkably, E1 and E'1 partially align 
with mouse E1b and E1c, respectively (L Bronicki and BJ Jasmin, unpubl.), implying that the developmental regulation and function of these two mammalian exons is evolutionarily conserved.

In addition to shedding light on the $5^{\prime}$ genomic region of $\mathrm{HuD}$, some studies, including from our laboratory, have contributed to the understanding of the trans-acting factors and cis-acting elements that control transcription of $H u D$. Prior to our study, only two transcriptional mechanisms were known to regulate expression of the $\mathrm{HuD}$ gene-thyroid hormone (T3; presumably via activation of the thyroid hormone receptor) and TF forkhead box O1 (FoxO1) - and both of these factors were shown to negatively impact the abundance of $\mathrm{HuD}$. T3 was demonstrated to decrease $\mathrm{HuD}$ mRNA synthesis in neuronal N2a cells, and T3 levels were inversely correlated with $H u D$ mRNA levels in the rat brain (Cuadrado et al. 2003), whereas FoxO1 was recently found to negatively regulate transcription of $H u D$ under low glucose conditions in pancreatic $\beta$ cells (Lee et al. 2012). These findings raise the possibility that one or both of these transcriptional events maintain low/inhibit $\mathrm{HuD}$ expression in nonneuronal and neuronal precursor/stem cells.

Research in our laboratory has revealed that the induction of $\mathrm{HuD}$ during early neuronal differentiation of P19 cells, a multipotent embryonal carcinoma cell line, is under neuron-specific transcriptional control (Bronicki et al. 2012). Additionally, we demonstrated that a highly conserved 400bp region upstream of the predominantly expressed E1 variant, E1c, houses several E-boxes, two of which are targeted by the basic helix-loop-helix transcription factor Neurogenin 2 (Ngn2). Importantly, using a combination of promoter-reporter assays, chromatin IPs, and electrophoretic mobility shift assays, we showed that Ngn2 binds these two E-boxes to promote expression of $\mathrm{HuD}$ only in cells differentiating into neurons. Given the established function of Ngn2 in neurogenesis (Guillemot 2007) and its emerging roles in learning and memory (Galichet et al. 2008) and neuronal diseases (Rostomily et al. 1997; Andersson et al. 2006; Kele et al. 2006; Uhrig et al. 2009), our findings suggest that Ngn2-dependent control of $\mathrm{HuD}$ transcription is central to neuronal development, function, and dysfunction (Fig. 4D).

\section{FUNCTIONAL ROLES OF HuD IN THE NERVOUS SYSTEM}

The multiple post-transcriptional effects exerted by $\mathrm{HuD}$ on mRNAs whose proteins have key roles in neurons (Table 2) and its expansive spatiotemporal expression within the nervous system strongly suggest that $\mathrm{HuD}$ acts as a "master regulator" of various neuronal processes (Deschenes-Furry et al. 2006; Perrone-Bizzozero and Bird 2013). Although the mostestablished role of $\mathrm{HuD}$ is in neurogenesis, studies are surfacing depicting its importance in neuronal function and survival, as well as plasticity during learning and memory and following neuronal injury. Additionally, there is accumulat- ing support implicating misregulation and mutation of $\mathrm{HuD}$ in neuronal pathologies and neuroendocrine cancers, further stressing the significance of this protein in the nervous system.

\section{Neuronal development}

Multiple studies on primary and cultured neuronal cells have demonstrated that $\mathrm{HuD}$ controls almost all stages of a neuron's existence, including neuronal commitment, differentiation, and activity (Deschenes-Furry et al. 2006; Pascale and Govoni 2012). For example, neurosphere assays using neuronal stem/progenitor cells from the cerebral cortex of $\mathrm{HuD}$ knockout (-/-) mice revealed that HuD decreases self-renewal capacity and promotes cell cycle exit and differentiation of these cells. Adult $\mathrm{HuD}-/-$ mice were also found to contain an increased number of self-renewing cells in the subventricular zone (SVZ), illustrating in vivo the importance of $\mathrm{HuD}$ for inhibition of neuronal stem/progenitor cell self-renewal (Akamatsu et al. 2005). The ability of HuD to control these early differentiation processes requires post-transcriptional regulation of specific target transcripts such as mRNAs encoding cyclin-dependent kinase p2 $1^{\text {cip1/waf1 }}$ (Fujiwara et al. 2006). Moreover, HuD-dependent neurogenesis requires commitment of cells to the neuronal lineage since ectopic expression of $\mathrm{HuD}$ in nonneuronal cells does not result in neuronal differentiation (Wakamatsu and Weston 1997).

Studies in which HuD levels were down-regulated or overexpressed in cultured cells have revealed an essential role for $\mathrm{HuD}$ in terminal differentiation, namely dendritic and axonal outgrowth (Wakamatsu and Weston 1997; Aranda-Abreu et al. 1999; Mobarak et al. 2000; Anderson et al. 2001; Hubers et al. 2010). In support of these findings, transgenic mice ectopically expressing $\mathrm{HuD}(\mathrm{HuD}-\mathrm{Tg}$ ) in forebrain neurons under the control of the CAMKIIa promoter (Bolognani et al. 2007b) were shown to contain increased mossy fiber length (Perrone-Bizzozero et al. 2011). Conversely, detailed analysis of $\mathrm{HuD}-/-$ mice revealed a transient impairment in neurite extension of several cranial nerves around day 10.5 of embryonic development (Akamatsu et al. 2005). These studies provide a clear demonstration that $\mathrm{HuD}$ positively regulates neurite outgrowth. This function of $\mathrm{HuD}$ requires its shuttling to the cytoplasm and involves stabilization of various target mRNAs whose protein products promote microtubule assembly and growth cone development including GAP-43, Tau, and AChE (Chung et al. 1997; Aranda-Abreu et al. 1999; Kasashima et al. 1999; DeschenesFurry et al. 2003).

\section{Neuronal plasticity}

Increasing evidence suggests that $\mathrm{HuD}$ also plays a role in different types of neuronal plasticity. In adult $\mathrm{HuD}-/-$ mice, an abnormal clasping reflex and poor performance on the rotarod test were observed, suggesting a sensory/motor defect 
in these animals and a role for $\mathrm{HuD}$ at the axon terminal (Akamatsu et al. 2005). Additionally, HuD has been implicated in axonal regeneration in two models of nerve injury. A study in our laboratory demonstrated that, between 1 and $4 \mathrm{~d}$ following axotomy of superior cervical ganglion (SCG) neurons, $\mathrm{HuD}$ protein and mRNA levels, its interaction with $A C h E$ mRNA, and AChE transcript levels decreased (Deschenes-Furry et al. 2007). Importantly, the reduction in AChE mRNA abundance could be rescued by localized overexpression of $\mathrm{HuD}$ delivered via a viral vector. Although $\mathrm{HuD}$ expression was shown to decrease immediately following nerve injury, another study performed nerve crush of dorsal root ganglion (DRG) neurons which resulted in an increase of $\mathrm{HuD}$ protein and GAP-43 mRNA expression within $7 \mathrm{~d}$, lasting up to $21 \mathrm{~d}$ post-injury (Anderson et al. 2003). These two studies provide a strong indication that the eventual up-regulation of endogenous $\mathrm{HuD}$ levels post-nerve injury may be involved in axonal recovery following nerve damage. Thus increases in $\mathrm{HuD}$ levels after nerve injury may facilitate regeneration.

In parallel with this potential role, studies have demonstrated that $\mathrm{HuD}$ protein levels, as well as a cohort of its target mRNAs such as GAP-43, CAMKIIa and Homer, increase in several brain regions including the dentate gyrus (DG) following neurotoxin-induced seizure (Bolognani et al. 2007a; Tiruchinapalli et al. 2008a; Winden et al. 2011). Moreover, glutamate receptor activation following cocaine treatment was shown to increase $\mathrm{HuD}$ protein and target mRNA abundance (e.g., GAP-43) and promote HuD localization to dendritic spines (Tiruchinapalli et al. 2008a). Along with the finding that several HuD-targeted mRNAs encode synaptic proteins (Bolognani et al. 2010), these studies indicate that $\mathrm{HuD}$ is important for various types of neuronal plasticity, potentially by directly acting at the synapse. However, further studies are necessary to elucidate the precise role of $\mathrm{HuD}$ in these forms of neuronal plasticity.

The function of $\mathrm{HuD}$ in neurogenesis and neuronal plasticity raised the possibility that it is also involved in hippocampus-dependent learning and memory. The first studies to link HuD to learning and memory demonstrated that expression of nELAV proteins and GAP-43 mRNA increased in the cytoskeletal and membrane fractions of murine hippocampal neurons following spatial discrimination tasks (Quattrone et al. 2001; Pascale et al. 2004). Closer inspection of $\mathrm{HuD}$ expression revealed increased $\mathrm{HuD}$ protein levels in somatic and dendritic compartments of hilar and CA3 hippocampal neurons following a different learning paradigm, contextual fear conditioning (Bolognani et al. 2004). To further study the role of $\mathrm{HuD}$ in learning and memory, HuD$\mathrm{Tg}$ mice were employed since these mice express $\mathrm{HuD}$ throughout the forebrain, including the hippocampus and cerebral cortex (Bolognani et al. 2006). Detailed analysis of these mice showed enhanced sprouting of GAP-43-containing mossy fibers to the CA3 region, ectopic expression of GAP-43 protein in the DG, and increased GAP-43 and calmodulin binding, possibly causing altered calcium signalling (Tanner et al. 2008). Furthermore, as mentioned above, microarray analysis of HuD-targeted mRNAs in DGCs demonstrated that $\mathrm{HuD}$-Tg mice contained increased expression of transcripts whose products regulate neuronal development and axogenesis (Perrone-Bizzozero et al. 2011). Although these mice displayed physiological and molecular alterations including ectopic HuD protein expression throughout the hippocampus, they exhibited aberrant acquisition and retention of memories possibly due to the lack of strict temporal and spatial regulation of $\mathrm{HuD}$ protein (Bolognani et al. 2007b). Based on these findings, it was concluded that the precise spatiotemporal control of $\mathrm{HuD}$ levels is necessary for proper learning and memory.

\section{Neurological disorders}

Given its multiple important roles in neurons, it is not surprising that misregulation or misexpression of $\mathrm{HuD}$ is implicated in several neural pathologies and tumors (Pascale and Govoni 2012; Perrone-Bizzozero and Bird 2013). In accordance with its direct or indirect function in learning and memory, nELAVs have recently been linked to Alzheimer's disease $(A D)$, a condition characterized by neuronal death, memory loss and eventual dementia. One hypothesis for the pathogenesis of $\mathrm{AD}$ revolves around cleavage of the amyloid precursor proteins (APPs) into $\beta$-amyloid (A $\beta$ ) fragments, a process that is promoted and prevented by $\beta$ and $\alpha$-secretase enzymes, respectively. Under nondisease conditions, $a$-secretases such as A disintegrin and metalloproteinase 10 (ADAM10) cleave APP to generate a growth promoting and neuroprotective fragment, soluble APPa, whereas in AD, several small $A \beta$ fragments are produced by $\beta$ and $\gamma$ secretases (Claeysen et al. 2012). One of these $A \beta$ fragments, the self-aggregating $A \beta_{1-42}$, is increasingly generated and accumulates in the cerebral plaques of AD patients (Jarrett et al. 1993; Gandy 2005). In the hippocampus of $A D$ patients, nELAV protein abundance was found to decrease in parallel with clinical dementia progression, and their expression was inversely correlated with $\mathrm{A} \beta$ peptide levels both in vitro and in vivo (Amadio et al. 2009). The authors also determined that the interaction between nELAV proteins and ADAM10 mRNA was disrupted following exposure to $A \beta_{1-42}$ leading to reduced ADAM10 protein levels (Amadio et al. 2009). These studies suggest that the decrease in nELAV protein levels leads to reduced ADAM10 expression which may be an important event in the development of $\mathrm{AD}$.

In addition to its potential role in $\mathrm{AD}$, three separate cohort genetic studies have linked single nucleotide polymorphisms (SNPs) within the $H u D$ locus to the development of Parkinson's disease (PD), a degenerative disorder of the CNS. The first of these studies genotyped nine SNPs in the $H u D$ gene locus from a Caucasian population and found that two of them, one in the first intron (rs967582) and one in the coding region (rs2494876), were associated 
with age at onset (AAO) of PD (Noureddine et al. 2005). A second study analyzed five SNPs in the HuD locus from Norwegian, United States, and Irish PD and control samples and found that two SNPs (rs967582 and rs3902720) are associated with AAO of PD but only in Irish patient samples, possibly due to a Celtic founder effect (Haugarvoll et al. 2007). Last, a subsequent study employed samples from a Caucasian population to confirm that the rs 967582 SNP is associated with increased risk of PD (DeStefano et al. 2008).

Also of particular relevance is the possible role of $\mathrm{HuD}$ in spinal muscular atrophy (SMA), a disease that results in degeneration of spinal cord motor neurons due to deletion or loss-of-function mutations in the survival of motor neuron 1 (SMN1) gene, resulting in inadequate expression of functional SMN protein (Burghes and Beattie 2009). A series of cell imaging and biochemical experiments in three independent studies demonstrated that $\mathrm{HuD}$ interacts with SMN protein in axonal compartments of neurons (Hubers et al. 2010; Akten et al. 2011; Fallini et al. 2011). Importantly, overexpression of $\mathrm{HuD}$ or of one of its target mRNAs ( $c p g$ 15) was found to partially rescue SMA-like defects related to cell morphology and recruitment of specific mRNAs into RNA granules (Hubers et al. 2010; Akten et al. 2011).

In line with its potential role in SMA, HuD has recently been associated with amyotropic lateral sclerosis (ALS), a neurodegenerative disorder resulting in progressive and fatal deterioration of upper and lower motor neurons (Pratt et al. 2012). Degenerating motor neurons in ALS patients commonly display cytoplasmic aggregates containing the DNA/ RNA-binding protein TDP-43 (Neumann et al. 2006). Biochemical and cell imaging techniques were used to demonstrate that TDP-43 associates with HuD and that TDP-43containing cytoplasmic aggregates sequester $\mathrm{HuD}$, suggesting that misregulation of mRNA metabolism in the cytoplasm of motor neurons could be involved in the development of ALS (Fallini et al. 2012a).

$\mathrm{HuD}$ has also been linked to schizophrenia, a psychiatric disorder in which patients often experience hallucinations, dementia, and impaired cognition. One study employed a DNA microarray on samples from patients with chronic schizophrenia and determined that $\mathrm{HuD}$ transcript levels were increased in the dorsolateral prefrontal cortex (Hakak et al. 2001). The authors also found that there was augmented abundance of several mRNAs including those encoding proteins involved in neuronal development, synaptic plasticity, and neurotransmission. Interestingly, some of these mRNAs, such as GAP-43, are targets of $\mathrm{HuD}$, indicating that increased levels of $\mathrm{HuD}$ in brains of schizophrenic patients may lead to altered post-transcriptional control and, consequently, an abundance of various $\mathrm{HuD}$-targeted mRNA products (Perrone-Bizzozero and Bird 2013).

Converging studies have also implicated $\mathrm{HuD}$ in epilepsy, a neurological syndrome hallmarked by seizures. Using kainic acid to induce seizures in adult male rats, one study found that this treatment produced increased $H u D$ and GAP-43
mRNA levels in the DG (Bolognani et al. 2007a). Another report used immunocytochemistry and Western blot techniques to demonstrate increased dendritic localization of $\mathrm{HuD}$ in hippocampal neurons following pilocarpine-induced seizure (Tiruchinapalli et al. 2008a). Furthermore, this study illustrated via RNA IP and quantitative RT-PCR that several HuD-targeted mRNAs such as GAP-43 and Neuritin also increased after seizures. A third study assessed gene expression using microarray platforms to show that $H u D$ and several of its target mRNAs increased following kainic acid-induced seizures in rats (Winden et al. 2011). Based on these studies, it is tempting to speculate that the increase in $\mathrm{HuD}$ and its target mRNAs following seizure is a protective mechanism to minimize neurodegeneration.

Evidence is also mounting that $\mathrm{HuD}$ plays a role in certain types of cancers. Aberrant expression or function of $\mathrm{HuD}$ has been detected in several cancers of the central and peripheral nervous system, most prominently NBs and SCLCs (Szabo et al. 1991; Dalmau et al. 1992; Chagnovich and Cohn 1996; Ball and King 1997; Schramm et al. 1999; Stawski et al. 2012). For instance, in $\sim 40 \%$ of NB tumors, there is a partial or complete deletion of the short arm (p) in one chromosome 1 homolog, which encompasses the $H u D$ gene locus (Muresu et al. 1994; Maris et al. 1995). In these cells, haploinsufficiency of $\mathrm{HuD}$ is thought to promote amplification of the N-myc gene and result in poor patient outcome (Grandinetti et al. 2006). Conversely, high levels of $\mathrm{HuD}$ and other nELAVs in NBs have been associated with a clinically favorable prognosis (Ball and King 1997). In line with this, a recent study screened various neuroendocrine lung tumors and found 11 mutations of unidentified consequence(s) and two mutations that prevent full-length protein expression in the $\mathrm{HuD}$ gene (D'Alessandro et al. 2010). Together, these findings imply that deletions or mutations of the $H u D$ gene are associated with the etiology or progression of certain neuroendocrine cancers.

\section{CONCLUSION AND PERSPECTIVE}

The Hu member HuD is one of the earliest markers of the neuronal phenotype and is broadly expressed in the mature nervous system. $\mathrm{HuD}$ targets specific mRNAs to regulate multiple levels of their metabolism, including nuclear processing, mRNA stability, and translation. Through post-transcriptional regulation of various neuronal mRNAs, $\mathrm{HuD}$ has key roles in neurons, among which neuronal differentiation is the best described. In addition to this function, increasing evidence implicates $\mathrm{HuD}$ in neuronal plasticity, nerve injury, learning and memory, and multiple neuronal diseases. In light of the important roles attributed to $\mathrm{HuD}$ in developing and mature neurons, a few studies have started to elucidate the cellular and molecular events governing its expression and function. An emerging picture reveals elaborate regulation of HuD expression, notably at the transcriptional and post-transcriptional levels, since the $H u D$ gene may contain 
multiple promoters and harbors eight exon 1 variants and an extensive $3^{\prime}$ UTR. Accordingly, it is tempting to speculate that the alternative promoters and encoded 5' UTRs (and possibly $\mathrm{N}$ termini) are essential for proper spatiotemporal control of $\mathrm{HuD}$ expression and function in neurons. For instance, aberrant abundance of the predominant $\mathrm{HuD}$ exon 1 variant, E1c, may occur in pathologies such as $\mathrm{AD}$, leading to improper localization of $\mathrm{HuD}$ or post-transcriptional regulation of certain HuD-targeted mRNAs. Despite the recent progress, there is still a lack of knowledge of the molecular mechanisms presiding over the "master regulator" $\mathrm{HuD}$, and thus, it becomes evident that a complete elucidation of these events is critical for improving our fundamental understanding of neuronal development, function, and diseases. Furthermore and equally important, a better comprehension of these events could ultimately lead to the development of therapeutic approaches for the treatment of neuronal injuries and disorders.

\section{ACKNOWLEDGMENTS}

We thank the current and past members of the Jasmin laboratory for their dedicated work and insightful discussions over the last several years. Over the years, funding of the Jasmin lab has been obtained from the Canadian Institute of Health Research, Muscular Dystrophy Association (MDA), Muscular Dystrophy Canada (MDC), L'Association Française contre les Myopathies (AFM), Canadian Institute of Health Research-Neuromuscular Research Partnership (CIHR-NRP), Jesse's Journey, Canadian Space Agency (CSA), the Rachel Fund, and Ontario Neurotrauma Foundation (ONF).

\section{REFERENCES}

Abdelmohsen K, Hutchison ER, Lee EK, Kuwano Y, Kim MM, Masuda K, Srikantan S, Subaran SS, Marasa BS, Mattson MP, et al. 2010. miR-375 inhibits differentiation of neurites by lowering HuD levels. Mol Cell Biol 30: 4197-4210.

Abe R, Uyeno Y, Yamamoto K, Sakamoto H. 1994. Tissue-specific expression of the gene encoding a mouse RNA binding protein homologous to human HuD antigen. DNA Res 1: 175-180.

Akamatsu W, Fujihara H, Mitsuhashi T, Yano M, Shibata S, Hayakawa Y, Okano HJ, Sakakibara S, Takano H, Takano T, et al. 2005. The RNA-binding protein HuD regulates neuronal cell identity and maturation. Proc Natl Acad Sci 102: 4625-4630.

Akten B, Kye MJ, Hao le T, Wertz MH, Singh S, Nie D, Huang J, Merianda TT, Twiss JL, Beattie CE, et al. 2011. Interaction of survival of motor neuron (SMN) and HuD proteins with mRNA cpg15 rescues motor neuron axonal deficits. Proc Natl Acad Sci 108: 1033710342.

Amadio M, Battaini F, Pascale A. 2006. The different facets of protein kinases C: Old and new players in neuronal signal transduction pathways. Pharmacol Res 54: 317-325.

Amadio M, Pascale A, Wang J, Ho L, Quattrone A, Gandy S, Haroutunian V, Racchi M, Pasinetti GM. 2009. nELAV proteins alteration in Alzheimer's disease brain: A novel putative target for amyloid- $\beta$ reverberating on $\mathrm{A} \beta \mathrm{PP}$ processing. J Alzheimers Dis 16: 409-419.

Anant S, Henderson JO, Mukhopadhyay D, Navaratnam N, Kennedy S, Min J, Davidson NO. 2001. Novel role for RNA-binding protein CUGBP2 in mammalian RNA editing. CUGBP2 modulates $\mathrm{C}$ to $\mathrm{U}$ editing of apolipoprotein $\mathrm{B}$ mRNA by interacting with apobec-1 and ACF, the apobec-1 complementation factor. J Biol Chem 276: $47338-47351$.

Anderson KD, Morin MA, Beckel-Mitchener A, Mobarak CD, Neve RL, Furneaux HM, Burry R, Perrone-Bizzozero NI. 2000. Overexpression of $\mathrm{HuD}$, but not of its truncated form HuD I+II, promotes GAP-43 gene expression and neurite outgrowth in PC12 cells in the absence of nerve growth factor. J Neurochem 75: 1103-1114.

Anderson KD, Sengupta J, Morin M, Neve RL, Valenzuela CF, PerroneBizzozero NI. 2001. Overexpression of HuD accelerates neurite outgrowth and increases GAP-43 mRNA expression in cortical neurons and retinoic acid-induced embryonic stem cells in vitro. Exp Neurol 168: $250-258$.

Anderson KD, Merhege MA, Morin M, Bolognani F, PerroneBizzozero NI. 2003. Increased expression and localization of the RNA-binding protein $\mathrm{HuD}$ and GAP-43 mRNA to cytoplasmic granules in DRG neurons during nerve regeneration. Exp Neurol 183: $100-108$.

Andersson E, Jensen JB, Parmar M, Guillemot F, Bjorklund A. 2006. Development of the mesencephalic dopaminergic neuron system is compromised in the absence of neurogenin 2. Development 133: 507-516.

Antic D, Lu N, Keene JD. 1999. ELAV tumor antigen, Hel-N1, increases translation of neurofilament M mRNA and induces formation of neurites in human teratocarcinoma cells. Genes Dev 13: 449-461.

Aranda-Abreu GE, Behar L, Chung S, Furneaux H, Ginzburg I. 1999. Embryonic lethal abnormal vision-like RNA-binding proteins regulate neurite outgrowth and tau expression in PC12 cells. J Neurosci 19: 6907-6917.

Aronov S, Aranda G, Behar L, Ginzburg I. 2002. Visualization of translated tau protein in the axons of neuronal P19 cells and characterization of tau RNP granules. J Cell Sci 115: 3817-3827.

Atlas R, Behar L, Elliott E, Ginzburg I. 2004. The insulin-like growth factor mRNA binding-protein IMP-1 and the Ras-regulatory protein G3BP associate with tau mRNA and HuD protein in differentiated P19 neuronal cells. J Neurochem 89: 613-626.

Atlas R, Behar L, Sapoznik S, Ginzburg I. 2007. Dynamic association with polysomes during P19 neuronal differentiation and an untranslated-region-dependent translation regulation of the tau mRNA by the tau mRNA-associated proteins IMP1, HuD, and G3BP1. $J$ Neurosci Res 85: 173-183.

Bakheet T, Williams BR, Khabar KS. 2003. ARED 2.0: An update of AU-rich element mRNA database. Nucleic Acids Res 31: 421-423.

Bakheet T, Williams BR, Khabar KS. 2006. ARED 3.0: The large and diverse AU-rich transcriptome. Nucleic Acids Res 34: D111D114.

Ball NS, King PH. 1997. Neuron-specific hel-N1 and HuD as novel molecular markers of neuroblastoma: A correlation of $\mathrm{HuD}$ messenger RNA levels with favorable prognostic features. Clin Cancer Res 3: 1859-1865.

Barreau C, Paillard L, Osborne HB. 2006. AU-rich elements and associated factors: Are there unifying principles? Nucleic Acids Res 33: 7138-7150.

Beckel-Mitchener AC, Miera A, Keller R, Perrone-Bizzozero NI. 2002. Poly(A) tail length-dependent stabilization of GAP-43 mRNA by the RNA-binding protein HuD. J Biol Chem 277: 27996-28002.

Bedford MT, Clarke SG. 2009. Protein arginine methylation in mammals: Who, what, and why. Mol Cell 33: 1-13.

Bell LR, Maine EM, Schedl P, Cline TW. 1988. Sex-lethal, a Drosophila sex determination switch gene, exhibits sex-specific RNA splicing and sequence similarity to RNA binding proteins. Cell 55: 1037-1046.

Bellavia D, Mecarozzi M, Campese AF, Grazioli P, Talora C, Frati L, Gulino A, Screpanti I. 2007. Notch3 and the Notch3-upregulated RNA-binding protein $\mathrm{HuD}$ regulate Ikaros alternative splicing. EMBO J 26: $1670-1680$.

Bitel CL, Perrone-Bizzozero NI, Frederikse PH. 2010. HuB/C/D, nPTB, REST4, and miR-124 regulators of neuronal cell identity are also utilized in the lens. Mol Vis 16: 2301-2316.

Bolognani F, Merhege MA, Twiss J, Perrone-Bizzozero NI. 2004. Dendritic localization of the RNA-binding protein $\mathrm{HuD}$ in hippocampal 
neurons: Association with polysomes and upregulation during contextual learning. Neurosci Lett 371: 152-157.

Bolognani F, Tanner DC, Merhege M, Deschenes-Furry J, Jasmin B, Perrone-Bizzozero NI. 2006. In vivo post-transcriptional regulation of GAP-43 mRNA by overexpression of the RNA-binding protein HuD. J Neurochem 96: 790-801.

Bolognani F, Tanner DC, Nixon S, Okano HJ, Okano H, PerroneBizzozero NI. 2007a. Coordinated expression of HuD and GAP-43 in hippocampal dentate granule cells during developmental and adult plasticity. Neurochem Res 32: 2142-2151.

Bolognani F, Qiu S, Tanner DC, Paik J, Perrone-Bizzozero NI, Weeber EJ. 2007b. Associative and spatial learning and memory deficits in transgenic mice overexpressing the RNA-binding protein HuD. Neurobiol Learn Mem 87: 635-643.

Bolognani F, Contente-Cuomo T, Perrone-Bizzozero NI. 2010. Novel recognition motifs and biological functions of the RNA-binding protein $\mathrm{HuD}$ revealed by genome-wide identification of its targets. Nucleic Acids Res 38: 117-130.

Borgeson CD, Samson ML. 2005. Shared RNA-binding sites for interacting members of the Drosophila ELAV family of neuronal proteins. Nucleic Acids Res 33: 6372-6383.

Brennan CM, Steitz JA. 2001. HuR and mRNA stability. Cell Mol Life Sci 58: 266-277.

Brewer G. 1991. An A + U-rich element RNA-binding factor regulates c-myc mRNA stability in vitro. Mol Cell Biol 11: 2460-2466.

Brewer G, Ross J. 1989. Regulation of c-myc mRNA stability in vitro by a labile destabilizer with an essential nucleic acid component. Mol Cell Biol 9: 1996-2006.

Briata P, Chen CY, Ramos A, Gherzi R. 2012. Functional and molecular insights into KSRP function in mRNA decay. Biochim Biophys Acta S1874-9399(12)00201-5. doi: 10.1016/j.bbagrm.2012.11.003.

Bronicki LM, Jasmin BJ. 2012. Trans-acting factors governing acetylcholinesterase mRNA metabolism in neurons. Front Mol Neurosci 5: 36.

Bronicki LM, Belanger G, Jasmin BJ. 2012. Characterization of multiple exon 1 variants in mammalian $\mathrm{HuD}$ mRNA and neuron-specific transcriptional control via neurogenin 2. J Neurosci 32: 11164-11175.

Burghes AH, Beattie CE. 2009. Spinal muscular atrophy: Why do low levels of survival motor neuron protein make motor neurons sick? Nat Rev Neurosci 10: 597-609.

Burry RW, Smith CL. 2006. HuD distribution changes in response to heat shock but not neurotrophic stimulation.J Histochem Cytochem 54: 1129-1138.

Carballo E, Lai WS, Blackshear PJ. 1998. Feedback inhibition of macrophage tumor necrosis factor- $\alpha$ production by tristetraprolin. Science 281: 1001-1005.

Carmody SR, Wente SR. 2009. mRNA nuclear export at a glance. J Cell Sci 122: 1933-1937.

Carninci P. 2010. RNA dust: Where are the genes? DNA Res 17: 51-59.

Chagnovich D, Cohn SL. 1996. Binding of a $40-\mathrm{kDa}$ protein to the N$m y c 3^{\prime}$-untranslated region correlates with enhanced $\mathrm{N}-m y c$ expression in human neuroblastoma. J Biol Chem 271: 33580-33586.

Chen CY, Gherzi R, Andersen JS, Gaietta G, Jurchott K, Royer HD, Mann M, Karin M. 2000. Nucleolin and YB-1 are required for JNK-mediated interleukin-2 mRNA stabilization during T-cell activation. Genes Dev 14: 1236-1248.

Chen CY, Gherzi R, Ong SE, Chan EL, Raijmakers R, Pruijn GJ, Stoecklin G, Moroni C, Mann M, Karin M. 2001. AU binding proteins recruit the exosome to degrade ARE-containing mRNAs. Cell 107: 451-464.

Chen HH, Xu J, Safarpour F, Stewart AF. 2007. LMO4 mRNA stability is regulated by extracellular ATP in F11 cells. Biochem Biophys Res Commun 357: 56-61.

Chung S, Jiang L, Cheng S, Furneaux H. 1996. Purification and properties of $\mathrm{HuD}$, a neuronal RNA-binding protein. J Biol Chem 271: 11518-11524.

Chung S, Eckrich M, Perrone-Bizzozero N, Kohn DT, Furneaux H. 1997. The Elav-like proteins bind to a conserved regulatory element in the $3^{\prime}$-untranslated region of GAP-43 mRNA. J Biol Chem 272: 6593-6598.
Claeysen S, Cochet M, Donneger R, Dumuis A, Bockaert J, Giannoni P. 2012. Alzheimer culprits: Cellular crossroads and interplay. Cell Signal 24: 1831-1840.

Clayton GH, Perez GM, Smith RL, Owens GC. 1998. Expression of mRNA for the elav-like neural-specific RNA binding protein, $\mathrm{HuD}$, during nervous system development. Brain Res Dev Brain Res 109: 271-280.

Clery A, Blatter M, Allain FH. 2008. RNA recognition motifs: Boring? Not quite. Curr Opin Struct Biol 18: 290-298.

Colombrita C, Silani V, Ratti A. 2013. ELAV proteins along evolution: Back to the nucleus? Mol Cell Neurosci S1044-7431(13)00021-3. doi: 10.1016/j.mcn.2013.02.003.

Cooper TA, Wan L, Dreyfuss G. 2009. RNA and disease. Cell 136: 777793.

Cuadrado A, Navarro-Yubero C, Furneaux H, Kinter J, Sonderegger P, Munoz A. 2002. HuD binds to three AU-rich sequences in the $3^{\prime}$ UTR of neuroserpin mRNA and promotes the accumulation of neuroserpin mRNA and protein. Nucleic Acids Res 30: 2202-2211.

Cuadrado A, Navarro-Yubero C, Furneaux H, Munoz A. 2003. Neuronal $\mathrm{HuD}$ gene encoding a mRNA stability regulator is transcriptionally repressed by thyroid hormone. J Neurochem 86: 763-773.

Dahan O, Gingold H, Pilpel Y. 2011. Regulatory mechanisms and networks couple the different phases of gene expression. Trends Genet 27: 316-322.

Dai W, Zhang G, Makeyev EV. 2012. RNA-binding protein HuR autoregulates its expression by promoting alternative polyadenylation site usage. Nucleic Acids Res 40: 787-800.

D’Alessandro V, Muscarella LA, la Torre A, Bisceglia M, Parrella P, Scaramuzzi G, Storlazzi CT, Trombetta D, Kok K, De Cata A, et al. 2010. Molecular analysis of the $\mathrm{HuD}$ gene in neuroendocrine lung cancers. Lung Cancer 67: 69-75.

Dalmau J, Furneaux HM, Gralla RJ, Kris MG, Posner JB. 1990. Detection of the anti-Hu antibody in the serum of patients with small cell lung cancer-a quantitative western blot analysis. Ann Neurol 27: 544-552.

Dalmau J, Graus F, Rosenblum MK, Posner JB. 1992. Anti-Hu-associated paraneoplastic encephalomyelitis/sensory neuronopathy. A clinical study of 71 patients. Medicine (Baltimore) 71: 59-72.

Darnell RB. 2006. Developing global insight into RNA regulation. Cold Spring Harb Symp Quant Biol 71: 321-327.

D’Autreaux F, Margolis KG, Roberts J, Stevanovic K, Mawe G, Li Z, Karamooz N, Ahuja A, Morikawa Y, Cserjesi P, et al. 2011. Expression level of Hand2 affects specification of enteric neurons and gastrointestinal function in mice. Gastroenterology 141: 576-587.

David PS, Tanveer R, Port JD. 2007. FRET-detectable interactions between the ARE binding proteins, HuR and p37AUF1. RNA 13: 1453-1468.

David Gerecht PS, Taylor MA, Port JD. 2010. Intracellular localization and interaction of mRNA binding proteins as detected by FRET. BMC Cell Biol 11: 69.

Davis-Smyth T, Duncan RC, Zheng T, Michelotti G, Levens D. 1996. The far upstream element-binding proteins comprise an ancient family of single-strand DNA-binding transactivators. J Biol Chem 271: 31679-31687.

Davuluri RV, Suzuki Y, Sugano S, Plass C, Huang TH. 2008. The functional consequences of alternative promoter use in mammalian genomes. Trends Genet 24: 167-177.

Deschenes-Furry J, Belanger G, Perrone-Bizzozero N, Jasmin BJ. 2003. Post-transcriptional regulation of acetylcholinesterase mRNAs in nerve growth factor-treated PC12 cells by the RNA-binding protein HuD. J Biol Chem 278: 5710-5717.

Deschenes-Furry J, Perrone-Bizzozero N, Jasmin BJ. 2006. The RNAbinding protein $\mathrm{HuD}$ : A regulator of neuronal differentiation, maintenance and plasticity. Bioessays 28: 822-833.

Deschenes-Furry J, Mousavi K, Bolognani F, Neve RL, Parks RJ, Perrone-Bizzozero NI, Jasmin BJ. 2007. The RNA-binding protein $\mathrm{HuD}$ binds acetylcholinesterase mRNA in neurons and regulates its expression after axotomy. J Neurosci 27: 665-675. 
Desroches-Castan A, Cherradi N, Feige JJ, Ciais D. 2011. A novel function of Tis $11 \mathrm{~b} / \mathrm{BRF} 1$ as a regulator of Dll4 mRNA $3^{\prime}$-end processing. Mol Biol Cell 22: 3625-3633.

DeStefano AL, Latourelle J, Lew MF, Suchowersky O, Klein C, Golbe LI, Mark MH, Growdon JH, Wooten GF, Watts R, et al. 2008. Replication of association between ELAVL4 and Parkinson disease: The GenePD study. Hum Genet 124: 95-99.

Devaux A, Colegrove-Otero LJ, Standart N. 2006. Xenopus ElrB, but not ElrA, binds RNA as an oligomer: Possible role of the linker. FEBS Lett 580: 4947-4952.

Donnini M, Lapucci A, Papucci L, Witort E, Jacquier A, Brewer G, Nicolin A, Capaccioli S, Schiavone N. 2004. Identification of TINO: A new evolutionarily conserved $B C L-2$ AU-rich element RNA-binding protein. J Biol Chem 279: 20154-20166.

Esteller M. 2011. Non-coding RNAs in human disease. Nat Rev Genet 12: $861-874$.

Fahling M, Steege A, Perlewitz A, Nafz B, Mrowka R, Persson PB, Thiele BJ. 2005. Role of nucleolin in posttranscriptional control of MMP-9 expression. Biochim Biophys Acta 1731: 32-40.

Fallini C, Zhang H, Su Y, Silani V, Singer RH, Rossoll W, Bassell GJ. 2011. The survival of motor neuron (SMN) protein interacts with the mRNA-binding protein $\mathrm{HuD}$ and regulates localization of poly(A) mRNA in primary motor neuron axons. J Neurosci 31: 3914-3925.

Fallini C, Bassell GJ, Rossoll W. 2012a. The ALS disease protein TDP-43 is actively transported in motor neuron axons and regulates axon outgrowth. Hum Mol Genet 21: 3703-3718.

Fallini C, Bassell GJ, Rossoll W. 2012b. Spinal muscular atrophy: The role of SMN in axonal mRNA regulation. Brain Res 1462: 81-92.

Fan XC, Steitz JA. 1998. Overexpression of HuR, a nuclear-cytoplasmic shuttling protein, increases the in vivo stability of ARE-containing mRNAs. EMBO J 17: 3448-3460.

Fialcowitz-White EJ, Brewer BY, Ballin JD, Willis CD, Toth EA, Wilson GM. 2007. Specific protein domains mediate cooperative assembly of HuR oligomers on AU-rich mRNA-destabilizing sequences. J Biol Chem 282: 20948-20959.

Fiesel FC, Kahle PJ. 2011. TDP-43 and FUS/TLS: Cellular functions and implications for neurodegeneration. FEBS J 278: 3550-3568.

Fujiwara T, Mori Y, Chu DL, Koyama Y, Miyata S, Tanaka H, Yachi K, Kubo T, Yoshikawa H, Tohyama M. 2006. CARM1 regulates proliferation of PC12 cells by methylating HuD. Mol Cell Biol 26: 2273-2285.

Fujiwara T, Fukao A, Sasano Y, Matsuzaki H, Kikkawa U, Imataka H, Inoue K, Endo S, Sonenberg N, Thoma C, et al. 2011a. Functional and direct interaction between the RNA binding protein $\mathrm{HuD}$ and active Akt1. Nucleic Acids Res 40: 1944-1953.

Fujiwara Y, Kasashima K, Saito K, Fukuda M, Fukao A, Sasano Y, Inoue K, Fujiwara T, Sakamoto H. 2011b. Microtubule association of a neuronal RNA-binding protein $\mathrm{HuD}$ through its binding to the light chain of MAP1B. Biochimie 93: 817-822.

Fukao A, Sasano Y, Imataka H, Inoue K, Sakamoto H, Sonenberg N, Thoma C, Fujiwara T. 2009. The ELAV protein HuD stimulates cap-dependent translation in a poly(A)- and eIF4A-dependent manner. Mol Cell 36: 1007-1017.

Galichet C, Guillemot F, Parras CM. 2008. Neurogenin 2 has an essential role in development of the dentate gyrus. Development 135: 20312041.

Gandy S. 2005. The role of cerebral amyloid $\beta$ accumulation in common forms of Alzheimer disease. J Clin Invest 115: 1121-1129.

Gao FB, Keene JD. 1996. Hel-N1/Hel-N2 proteins are bound to poly $(\mathrm{A})^{+}$mRNA in granular RNP structures and are implicated in neuronal differentiation. J Cell Sci 109 (Pt 3): 579-589.

Gherzi R, Lee KY, Briata P, Wegmuller D, Moroni C, Karin M, Chen CY. 2004. A KH domain RNA binding protein, KSRP, promotes ARE-directed mRNA turnover by recruiting the degradation machinery. Mol Cell 14: 571-583.

Good PJ. 1995. A conserved family of elav-like genes in vertebrates. Proc Natl Acad Sci 92: 4557-4561.

Grandinetti KB, Spengler BA, Biedler JL, Ross RA. 2006. Loss of one $\mathrm{HuD}$ allele on chromosome \#1p selects for amplification of the $\mathrm{N}$ - myc proto-oncogene in human neuroblastoma cells. Oncogene 25: 706-712.

Gratacos FM, Brewer G. 2010. The role of AUF1 in regulated mRNA decay. Wiley Interdiscip Rev RNA 1: 457-473.

Graus F, Elkon KB, Lloberes P, Ribalta T, Torres A, Ussetti P, Valls J, Obach J, Agusti-Vidal A. 1987. Neuronal antinuclear antibody (anti-Hu) in paraneoplastic encephalomyelitis simulating acute polyneuritis. Acta Neurol Scand 75: 249-252.

Guillemot F. 2007. Spatial and temporal specification of neural fates by transcription factor codes. Development 134: 3771-3780.

Hakak Y, Walker JR, Li C, Wong WH, Davis KL, Buxbaum JD, Haroutunian V, Fienberg AA. 2001. Genome-wide expression analysis reveals dysregulation of myelination-related genes in chronic schizophrenia. Proc Natl Acad Sci 98: 4746-4751.

Halees AS, El Badrawi R, Khabar KS. 2008. ARED organism: Expansion of ARED reveals AU-rich element cluster variations between human and mouse. Nucleic Acids Res 36: D137-D140.

Hambardzumyan D, Sergent-Tanguy S, Thinard R, Bonnamain V, Masip M, Fabre A, Boudin H, Neveu I, Naveilhan P. 2009. AUF1 and $\mathrm{Hu}$ proteins in the developing rat brain: Implication in the proliferation and differentiation of neural progenitors. J Neurosci Res 87: 1296-1309.

Haugarvoll K, Toft M, Ross OA, Stone JT, Heckman MG, White LR, Lynch T, Gibson JM, Wszolek ZK, Uitti RJ, et al. 2007. ELAVL4, PARK10, and the Celts. Mov Disord 22: 585-587.

Hilgers V, Lemke SB, Levine M. 2012. ELAV mediates 3' UTR extension in the Drosophila nervous system. Genes Dev 26: 2259-2264.

Hinman MN, Lou H. 2008. Diverse molecular functions of Hu proteins. Cell Mol Life Sci 65: 3168-3181.

Hubers L, Valderrama-Carvajal H, Laframboise J, Timbers J, Sanchez G, Cote J. 2010. HuD interacts with survival motor neuron protein and can rescue spinal muscular atrophy-like neuronal defects. Hum Mol Genet 20: 553-579.

Im HI, Kenny PJ. 2012. MicroRNAs in neuronal function and dysfunction. Trends Neurosci 35: 325-334.

Ince-Dunn G, Okano HJ, Jensen KB, Park WY, Zhong R, Ule J, Mele A, Fak JJ, Yang C, Zhang C, et al. 2012. Neuronal Elav-like (Hu) proteins regulate RNA splicing and abundance to control glutamate levels and neuronal excitability. Neuron 75: 1067-1080.

Inman MV, Levy S, Mock BA, Owens GC. 1998. Gene organization and chromosome location of the neural-specific RNA binding protein Elavl4. Gene 208: 139-145.

Izquierdo JM. 2008. Hu antigen R (HuR) functions as an alternative premRNA splicing regulator of Fas apoptosis-promoting receptor on exon definition. J Biol Chem 283: 19077-19084.

Jain RG, Andrews LG, McGowan KM, Pekala PH, Keene JD. 1997. Ectopic expression of Hel-N1, an RNA-binding protein, increases glucose transporter (GLUT1) expression in 3T3-L1 adipocytes. Mol Cell Biol 17: 954-962.

Jarrett JT, Berger EP, Lansbury PT Jr. 1993. The C-terminus of the $\beta$ protein is critical in amyloidogenesis. Ann N Y Acad Sci 695: 144-148.

Joseph B, Orlian M, Furneaux H. 1998. p21 ${ }^{\text {wafl }}$ mRNA contains a conserved element in its $3^{\prime}$-untranslated region that is bound by the Elav-like mRNA-stabilizing proteins. J Biol Chem 273: 20511-20516.

Kasashima K, Terashima K, Yamamoto K, Sakashita E, Sakamoto H. 1999. Cytoplasmic localization is required for the mammalian ELAV-like protein $\mathrm{HuD}$ to induce neuronal differentiation. Genes Cells 4: 667-683.

Kasashima K, Sakashita E, Saito K, Sakamoto H. 2002. Complex formation of the neuron-specific ELAV-like Hu RNA-binding proteins. Nucleic Acids Res 30: 4519-4526.

Keene JD. 2007. RNA regulons: Coordination of post-transcriptional events. Nat Rev Genet 8: 533-543.

Kele J, Simplicio N, Ferri AL, Mira H, Guillemot F, Arenas E, Ang SL. 2006. Neurogenin 2 is required for the development of ventral midbrain dopaminergic neurons. Development 133: 495-505.

Khabar KS. 2010. Post-transcriptional control during chronic inflammation and cancer: A focus on AU-rich elements. Cell Mol Life Sci 67: 2937-2955 
Khaleghpour K, Svitkin YV, Craig AW, DeMaria CT, Deo RC, Burley SK, Sonenberg N. 2001. Translational repression by a novel partner of human poly(A) binding protein, Paip2. Mol Cell 7: 205-216.

Kim YJ, Baker BS. 1993. The Drosophila gene $r b p 9$ encodes a protein that is a member of a conserved group of putative RNA binding proteins that are nervous system-specific in both flies and humans. J Neurosci 13: 1045-1056.

Kim HH, Kuwano Y, Srikantan S, Lee EK, Martindale JL, Gorospe M. 2009. HuR recruits let-7/RISC to repress c-Myc expression. Genes Dev 23: $1743-1748$.

King PH, Levine TD, Fremeau RT Jr, Keene JD. 1994. Mammalian homologs of Drosophila ELAV localized to a neuronal subset can bind in vitro to the $3^{\prime}$ UTR of mRNA encoding the Id transcriptional repressor. J Neurosci 14: 1943-1952.

Koushika SP, Lisbin MJ, White K. 1996. ELAV, a Drosophila neuronspecific protein, mediates the generation of an alternatively spliced neural protein isoform. Curr Biol 6: 1634-1641.

Krzyzosiak WJ, Sobczak K, Wojciechowska M, Fiszer A, Mykowska A, Kozlowski P. 2012. Triplet repeat RNA structure and its role as pathogenic agent and therapeutic target. Nucleic Acids Res 40: 11-26.

Kullmann M, Gopfert U, Siewe B, Hengst L. 2002. ELAV/Hu proteins inhibit p27 translation via an IRES element in the p27 $5^{\prime}$ UTR. Genes Dev 16: 3087-3099.

Lal A, Mazan-Mamczarz K, Kawai T, Yang X, Martindale JL, Gorospe M. 2004. Concurrent versus individual binding of HuR and AUF1 to common labile target mRNAs. EMBO J 23: 3092-3102.

Lazarova DL, Spengler BA, Biedler JL, Ross RA. 1999. HuD, a neuronalspecific RNA-binding protein, is a putative regulator of $\mathrm{N}-m y c$ premRNA processing/stability in malignant human neuroblasts. Oncogene 18: 2703-2710.

Lebedeva S, Jens M, Theil K, Schwanhausser B, Selbach M, Landthaler M, Rajewsky N. 2011. Transcriptome-wide analysis of regulatory interactions of the RNA-binding protein HuR. Mol Cell 43: 340-352.

Lee EK, Kim W, Tominaga K, Martindale JL, Yang X, Subaran SS, Carlson OD, Mercken EM, Kulkarni RN, Akamatsu W, et al. 2012. RNA-binding protein $\mathrm{HuD}$ controls insulin translation. Mol Cell 45: $826-835$.

Levine TD, Gao F, King PH, Andrews LG, Keene JD. 1993. Hel-N1: An autoimmune RNA-binding protein with specificity for 3' uridylaterich untranslated regions of growth factor mRNAs. Mol Cell Biol 13: 3494-3504.

Levy NS, Chung S, Furneaux H, Levy AP. 1998. Hypoxic stabilization of vascular endothelial growth factor mRNA by the RNA-binding protein HuR. J Biol Chem 273: 6417-6423.

Li Y, Jin P. 2012. RNA-mediated neurodegeneration in fragile X-associated tremor/ataxia syndrome. Brain Res 1462: 112-117.

Liang J, Lei T, Song Y, Yanes N, Qi Y, Fu M. 2009. RNA-destabilizing factor tristetraprolin negatively regulates NF- $\mathrm{\kappa B}$ signaling. $J$ Biol Chem 284: 29383-29390.

Liao B, Hu Y, Brewer G. 2007. Competitive binding of AUF1 and TIAR to MYC mRNA controls its translation. Nat Struct Mol Biol 14: 511-518.

Licatalosi DD, Darnell RB. 2010. RNA processing and its regulation: Global insights into biological networks. Nat Rev Genet 11: 75-87.

Lim CS, Alkon DL. 2012. Protein kinase C stimulates HuD-mediated mRNA stability and protein expression of neurotrophic factors and enhances dendritic maturation of hippocampal neurons in culture. Hippocampus 22: 2303-2319.

Liu J, Dalmau J, Szabo A, Rosenfeld M, Huber J, Furneaux H. 1995. Paraneoplastic encephalomyelitis antigens bind to the AU-rich elements of mRNA. Neurology 45: 544-550.

Lukong KE, Chang KW, Khandjian EW, Richard S. 2008. RNA-binding proteins in human genetic disease. Trends Genet 24: 416-425.

Ma WJ, Cheng S, Campbell C, Wright A, Furneaux H. 1996. Cloning and characterization of HuR, a ubiquitously expressed Elav-like protein. J Biol Chem 271: 8144-8151.

Ma WJ, Chung S, Furneaux H. 1997. The Elav-like proteins bind to AUrich elements and to the poly(A) tail of mRNA. Nucleic Acids Res 25: 3564-3569.
Maier DL, Mani S, Donovan SL, Soppet D, Tessarollo L, McCasland JS, Meiri KF. 1999. Disrupted cortical map and absence of cortical barrels in growth-associated protein (GAP)-43 knockout mice. Proc Natl Acad Sci 96: 9397-9402.

Mani S, Shen Y, Schaefer J, Meiri KF. 2001. Failure to express GAP-43 during neurogenesis affects cell cycle regulation and differentiation of neural precursors and stimulates apoptosis of neurons. Mol Cell Neurosci 17: 54-66.

Manohar CF, Short ML, Nguyen A, Nguyen NN, Chagnovich D, Yang Q, Cohn SL. 2002. HuD, a neuronal-specific RNA-binding protein, increases the in vivo stability of MYCN RNA. J Biol Chem 277: 1967-1973.

Mansfield KD, Keene JD. 2009. The ribonome: A dominant force in coordinating gene expression. Biol Cell 101: 169-181.

Mansfield KD, Keene JD. 2011. Neuron-specific ELAV/Hu proteins suppress HuR mRNA during neuronal differentiation by alternative polyadenylation. Nucleic Acids Res 40: 2734-2746.

Maris JM, White PS, Beltinger CP, Sulman EP, Castleberry RP, Shuster JJ, Look AT, Brodeur GM. 1995. Significance of chromosome 1p loss of heterozygosity in neuroblastoma. Cancer Res 55: 4664-4669.

Mazan-Mamczarz K, Galban S, Lopez de Silanes I, Martindale JL, Atasoy U, Keene JD, Gorospe M. 2003. RNA-binding protein HuR enhances p53 translation in response to ultraviolet light irradiation. Proc Natl Acad Sci 100: 8354-8359.

McKee AE, Minet E, Stern C, Riahi S, Stiles CD, Silver PA. 2005. A genome-wide in situ hybridization map of RNA-binding proteins reveals anatomically restricted expression in the developing mouse brain. BMC Dev Biol 5: 14.

Meng Z, King PH, Nabors LB, Jackson NL, Chen CY, Emanuel PD, Blume SW. 2005. The ELAV RNA-stability factor HuR binds the $5^{\prime}$-untranslated region of the human IGF-IR transcript and differentially represses cap-dependent and IRES-mediated translation. Nucleic Acids Res 33: 2962-2979.

Min H, Turck CW, Nikolic JM, Black DL. 1997. A new regulatory protein, KSRP, mediates exon inclusion through an intronic splicing enhancer. Genes Dev 11: 1023-1036.

Mobarak CD, Anderson KD, Morin M, Beckel-Mitchener A, Rogers SL, Furneaux H, King P, Perrone-Bizzozero NI. 2000. The RNA-binding protein $\mathrm{HuD}$ is required for GAP-43 mRNA stability, GAP-43 gene expression, and PKC-dependent neurite outgrowth in PC12 cells. Mol Biol Cell 11: 3191-3203.

Moraes KC, Wilusz CJ, Wilusz J. 2006. CUG-BP binds to RNA substrates and recruits PARN deadenylase. RNA 12: 1084-1091.

Mukherjee N, Corcoran DL, Nusbaum JD, Reid DW, Georgiev S, Hafner M, Ascano M Jr, Tuschl T, Ohler U, Keene JD. 2011. Integrative regulatory mapping indicates that the RNA-binding protein HuR couples pre-mRNA processing and mRNA stability. Mol Cell 43: 327-339.

Mukhopadhyay D, Houchen CW, Kennedy S, Dieckgraefe BK, Anant S. 2003. Coupled mRNA stabilization and translational silencing of cyclooxygenase- 2 by a novel RNA binding protein, CUGBP2. Mol Cell 11: 113-126.

Muresu R, Baldini A, Gress T, Posner JB, Furneaux HM, Siniscalco M. 1994. Mapping of the gene coding for a paraneoplastic encephalomyelitis antigen $(\mathrm{HuD})$ to human chromosome site 1p34. Cytogenet Cell Genet 65: 177-178.

Nassar F. 2011. Regulation and expression of elrD1 and elrD2 transcripts during early Xenopus laevis development. Int J Dev Biol 55: 127-132.

Nassar F, Wegnez M. 2001. Characterization of two promoters of the Xenopus laevis elrD gene. Biochem Biophys Res Commun 283: 392-398.

Neumann M, Sampathu DM, Kwong LK, Truax AC, Micsenyi MC, Chou TT, Bruce J, Schuck T, Grossman M, Clark CM, et al. 2006. Ubiquitinated TDP-43 in frontotemporal lobar degeneration and amyotrophic lateral sclerosis. Science 314: 130-133.

Noureddine MA, Qin XJ, Oliveira SA, Skelly TJ, van der Walt J, Hauser MA, Pericak-Vance MA, Vance JM, Li YJ. 2005. Association between the neuron-specific RNA-binding protein ELAVL4 and Parkinson disease. Hum Genet 117: 27-33. 
Okano HJ, Darnell RB. 1997. A hierarchy of Hu RNA binding proteins in developing and adult neurons. J Neurosci 17: 3024-3037.

Onesto C, Berra E, Grepin R, Pages G. 2004. Poly(A)-binding proteininteracting protein 2, a strong regulator of vascular endothelial growth factor mRNA. J Biol Chem 279: 34217-34226.

Park S, Myszka DG, Yu M, Littler SJ, Laird-Offringa IA. 2000. HuD RNA recognition motifs play distinct roles in the formation of a stable complex with AU-rich RNA. Mol Cell Biol 20: 4765-4772.

Pascale A, Govoni S. 2012. The complex world of post-transcriptional mechanisms: Is their deregulation a common link for diseases? Focus on ELAV-like RNA-binding proteins. Cell Mol Life Sci 69: 501-517.

Pascale A, Gusev PA, Amadio M, Dottorini T, Govoni S, Alkon DL, Quattrone A. 2004. Increase of the RNA-binding protein $\mathrm{HuD}$ and posttranscriptional up-regulation of the GAP-43 gene during spatial memory. Proc Natl Acad Sci 101: 1217-1222.

Pascale A, Amadio M, Scapagnini G, Lanni C, Racchi M, Provenzani A, Govoni S, Alkon DL, Quattrone A. 2005. Neuronal ELAV proteins enhance mRNA stability by a PKCa-dependent pathway. Proc Natl Acad Sci 102: 12065-12070.

Pascale A, Amadio M, Quattrone A. 2008. Defining a neuron: Neuronal ELAV proteins. Cell Mol Life Sci 65: 128-140.

Peng SS, Chen CY, Xu N, Shyu AB. 1998. RNA stabilization by the AUrich element binding protein, HuR, an ELAV protein. EMBO J 17: 3461-3470.

Perrone-Bizzozero N, Bird CW. 2013. Role of HuD in nervous system function and pathology. Front Biosci (Schol Ed) 5: 554-563.

Perrone-Bizzozero NI, Tanner DC, Mounce J, Bolognani F. 2011. Increased expression of axogenesis-related genes and mossy fibre length in dentate granule cells from adult $\mathrm{HuD}$ overexpressor mice. ASN Neuro 3: 259-270.

Pfeiffer JR, Brooks SA. 2012. Cullin 4B is recruited to tristetraprolincontaining messenger ribonucleoproteins and regulates TNF- $\alpha$ mRNA polysome loading. J Immunol 188: 1828-1839.

Philips AV, Timchenko LT, Cooper TA. 1998. Disruption of splicing regulated by a CUG-binding protein in myotonic dystrophy. Science 280: 737-741.

Pratt AJ, Getzoff ED, Perry JJ. 2012. Amyotrophic lateral sclerosis: Update and new developments. Degener Neurol Neuromuscul Dis 2012: 1-14.

Pullmann R Jr, Kim HH, Abdelmohsen K, Lal A, Martindale JL, Yang X, Gorospe M. 2007. Analysis of turnover and translation regulatory RNA-binding protein expression through binding to cognate mRNAs. Mol Cell Biol 27: 6265-6278.

Qi MY, Wang ZZ, Zhang Z, Shao Q, Zeng A, Li XQ, Li WQ, Wang C, Tian FJ, Li Q, et al. 2012. AU-rich-element-dependent translation repression requires the cooperation of tristetraprolin and RCK/ P54. Mol Cell Biol 32: 913-928.

Quattrone A, Pascale A, Nogues X, Zhao W, Gusev P, Pacini A, Alkon DL. 2001. Posttranscriptional regulation of gene expression in learning by the neuronal ELAV-like mRNA-stabilizing proteins. Proc Natl Acad Sci 98: 11668-11673.

Ratti A, Fallini C, Cova L, Fantozzi R, Calzarossa C, Zennaro E, Pascale A, Quattrone A, Silani V. 2006. A role for the ELAV RNAbinding proteins in neural stem cells: Stabilization of Msil mRNA. J Cell Sci 119: 1442-1452.

Ratti A, Fallini C, Colombrita C, Pascale A, Laforenza U, Quattrone A, Silani V. 2008. Post-transcriptional regulation of neuro-oncological ventral antigen 1 by the neuronal RNA-binding proteins ELAV. J Biol Chem 283: 7531-7541.

Robinow S, Campos AR, Yao KM, White K. 1988. The elav gene product of Drosophila, required in neurons, has three RNP consensus motifs. Science 242: 1570-1572.

Ross RA, Lazarova DL, Manley GT, Smitt PS, Spengler BA, Posner JB, Biedler JL. 1997. HuD, a neuronal-specific RNA-binding protein, is a potential regulator of $M Y C N$ expression in human neuroblastoma cells. Eur J Cancer 33: 2071-2074.

Rostomily RC, Bermingham-McDonogh O, Berger MS, Tapscott SJ, Reh TA, Olson JM. 1997. Expression of neurogenic basic helix- loop-helix genes in primitive neuroectodermal tumors. Cancer Res 57: 3526-3531.

Routtenberg A, Cantallops I, Zaffuto S, Serrano P, Namgung U. 2000. Enhanced learning after genetic overexpression of a brain growth protein. Proc Natl Acad Sci 97: 7657-7662.

Roux PP, Topisirovic I. 2012. Regulation of mRNA translation by signaling pathways. Cold Spring Harb Perspect Biol 4: a012252.

Saito K, Fujiwara T, Katahira J, Inoue K, Sakamoto H. 2004. TAP/NXF1, the primary mRNA export receptor, specifically interacts with a neuronal RNA-binding protein HuD. Biochem Biophys Res Commun 321: 291-297.

Sakai K, Gofuku M, Kitagawa Y, Ogasawara T, Hirose G, Yamazaki M, Koh CS, Yanagisawa N, Steinman L. 1994. A hippocampal protein associated with paraneoplastic neurologic syndrome and small cell lung carcinoma. Biochem Biophys Res Commun 199: 1200-1208.

Samson ML. 1998. Evidence for $3^{\prime}$ untranslated region-dependent autoregulation of the Drosophila gene encoding the neuronal nuclear RNA-binding protein ELAV. Genetics 150: 723-733.

Samson ML, Chalvet F. 2003. found in neurons, a third member of the Drosophila elav gene family, encodes a neuronal protein and interacts with elav. Mech Dev 120: 373-383.

Sanduja S, Blanco FF, Dixon DA. 2011. The roles of TTP and BRF proteins in regulated mRNA decay. Wiley Interdiscip Rev RNA 2: $42-57$.

Schichl YM, Resch U, Hofer-Warbinek R, de Martin R. 2009. Tristetraprolin impairs NF- $\mathrm{BB} / \mathrm{p} 65$ nuclear translocation. J Biol Chem 284: 29571-29581.

Schramm M, Falkai P, Pietsch T, Neidt I, Egensperger R, Bayer TA. 1999. Neural expression profile of Elav-like genes in human brain. Clin Neuropathol 18: 17-22.

Sekido Y, Bader SA, Carbone DP, Johnson BE, Minna JD. 1994. Molecular analysis of the $\mathrm{HuD}$ gene encoding a paraneoplastic encephalomyelitis antigen in human lung cancer cell lines. Cancer Res 54: 4988-4992.

Shen Y, Mishra R, Mani S, Meiri KF. 2008. Both cell-autonomous and cell non-autonomous functions of GAP-43 are required for normal patterning of the cerebellum in vivo. Cerebellum 7: 451-466.

Smith CL, Afroz R, Bassell GJ, Furneaux HM, Perrone-Bizzozero NI, Burry RW. 2004. GAP-43 mRNA in growth cones is associated with $\mathrm{HuD}$ and ribosomes. J Neurobiol 61: 222-235.

Snee M, Kidd GJ, Munro TP, Smith R. 2002. RNA trafficking and stabilization elements associate with multiple brain proteins. J Cell Sci 115: 4661-4669.

Soller M, White K. 2003. ELAV inhibits $3^{\prime}$-end processing to promote neural splicing of ewg pre-mRNA. Genes Dev 17: 2526-2538.

Stawski R, Piaskowski S, Stoczynska-Fidelus E, Wozniak K, Bienkowski M, Zakrzewska M, Witusik-Perkowska M, Jaskolski DJ, Och W, Papierz W, et al. 2012. Reduced expression of ELAVL4 in male meningioma patients. Brain Tumor Pathol doi: 10.1007/ s10014-012-0117-x.

Stoecklin G, Colombi M, Raineri I, Leuenberger S, Mallaun M, Schmidlin M, Gross B, Lu M, Kitamura T, Moroni C. 2002. Functional cloning of BRF1, a regulator of ARE-dependent mRNA turnover. EMBO J 21: 4709-4718.

Strong MJ, Volkening K. 2011. TDP-43 and FUS/TLS: Sending a complex message about messenger RNA in amyotrophic lateral sclerosis? FEBS J 278: 3569-3577.

Szabo A, Dalmau J, Manley G, Rosenfeld M, Wong E, Henson J, Posner JB, Furneaux HM. 1991. HuD, a paraneoplastic encephalomyelitis antigen, contains RNA-binding domains and is homologous to Elav and Sex-lethal. Cell 67: 325-333.

Takagi M, Absalon MJ, McLure KG, Kastan MB. 2005. Regulation of p53 translation and induction after DNA damage by ribosomal protein L26 and nucleolin. Cell 123: 49-63.

Tanner DC, Qiu S, Bolognani F, Partridge LD, Weeber EJ, PerroneBizzozero NI. 2008. Alterations in mossy fiber physiology and GAP-43 expression and function in transgenic mice overexpressing HuD. Hippocampus 18: 814-823. 
Tiedje C, Ronkina N, Tehrani M, Dhamija S, Laass K, Holtmann H, Kotlyarov A, Gaestel M. 2012. The p38/MK2-driven exchange between tristetraprolin and HuR regulates AU-rich element-dependent translation. PLoS Genet 8: e1002977.

Timchenko NA, Welm AL, Lu X, Timchenko LT. 1999. CUG repeat binding protein (CUGBP1) interacts with the $5^{\prime}$ region of C/EBP $\beta$ mRNA and regulates translation of C/EBP $\beta$ isoforms. Nucleic Acids Res 27: 4517-4525.

Tiruchinapalli DM, Caron MG, Keene JD. 2008a. Activity-dependent expression of ELAV/Hu RBPs and neuronal mRNAs in seizure and cocaine brain. J Neurochem 107: 1529-1543.

Tiruchinapalli DM, Ehlers MD, Keene JD. 2008b. Activity-dependent expression of RNA binding protein $\mathrm{HuD}$ and its association with mRNAs in neurons. RNA Biol 5: 157-168.

Toba G, White K. 2008. The third RNA recognition motif of Drosophila ELAV protein has a role in multimerization. Nucleic Acids Res 36: 1390-1399.

Toba G, Qui J, Koushika SP, White K. 2002. Ectopic expression of Drosophila ELAV and human $\mathrm{HuD}$ in Drosophila wing disc cells reveals functional distinctions and similarities. J Cell Sci 115: 24132421.

Tsai KC, Cansino VV, Kohn DT, Neve RL, Perrone-Bizzozero NI. 1997. Post-transcriptional regulation of the GAP-43 gene by specific sequences in the $3^{\prime}$ untranslated region of the mRNA. J Neurosci 17: 1950-1958.

Uhrig M, Ittrich C, Wiedmann V, Knyazev Y, Weninger A, Riemenschneider M, Hartmann T. 2009. New Alzheimer amyloid $\beta$ responsive genes identified in human neuroblastoma cells by hierarchical clustering. PLoS One 4: e6779.

Uren PJ, Burns SC, Ruan J, Singh KK, Smith AD, Penalva LO. 2011. Genomic analyses of the RNA-binding protein $\mathrm{Hu}$ antigen $\mathrm{R}$ (HuR) identify a complex network of target genes and novel characteristics of its binding sites. J Biol Chem 286: 37063-37066.

Vazquez-Pianzola P, Suter B. 2012. Conservation of the RNA transport machineries and their coupling to translation control across eukaryotes. Comp Funct Genomics 2012: 287852.

Wakamatsu Y, Weston JA. 1997. Sequential expression and role of Hu RNA-binding proteins during neurogenesis. Development 124: 3449-3460.
Wang X, Tanaka Hall TM. 2001. Structural basis for recognition of AUrich element RNA by the HuD protein. Nat Struct Biol 8: 141-145.

Wang H, Molfenter J, Zhu H, Lou H. 2010. Promotion of exon 6 inclusion in HuD pre-mRNA by Hu protein family members. Nucleic Acids Res 38: 3760-3770.

Wein G, Rossler M, Klug R, Herget T. 2003. The 3'-UTR of the mRNA coding for the major protein kinase $\mathrm{C}$ substrate MARCKS contains a novel CU-rich element interacting with the mRNA stabilizing factors $\mathrm{HuD}$ and HuR. Eur J Biochem 270: 350-365.

Winden KD, Karsten SL, Bragin A, Kudo LC, Gehman L, Ruidera J, Geschwind DH, Engel J Jr. 2011. A systems level, functional genomics analysis of chronic epilepsy. PLoS One 6: e20763.

Wu X, Brewer G. 2012. The regulation of mRNA stability in mammalian cells: 2.0. Gene 500: 10-21.

Yang TH, Tsai WH, Lee YM, Lei HY, Lai MY, Chen DS, Yeh NH, Lee SC. 1994. Purification and characterization of nucleolin and its identification as a transcription repressor. Mol Cell Biol 14: 6068-6074.

Zaidi SH, Malter JS. 1995. Nucleolin and heterogeneous nuclear ribonucleoprotein C proteins specifically interact with the $3^{\prime}$-untranslated region of amyloid protein precursor mRNA. J Biol Chem 270: 17292-17298.

Zhang W, Wagner BJ, Ehrenman K, Schaefer AW, DeMaria CT, Crater D, DeHaven K, Long L, Brewer G. 1993. Purification, characterization, and cDNA cloning of an AU-rich element RNA-binding protein, AUF1. Mol Cell Biol 13: 7652-7665.

Zhang W, Liu H, Han K, Grabowski PJ. 2002. Region-specific alternative splicing in the nervous system: Implications for regulation by the RNA-binding protein NAPOR. RNA 8: 671-685.

Zhou HL, Hinman MN, Barron VA, Geng C, Zhou G, Luo G, Siegel RE, Lou H. 2011. Hu proteins regulate alternative splicing by inducing localized histone hyperacetylation in an RNA-dependent manner. Proc Natl Acad Sci 108: E627-E635.

Zhu H, Hasman RA, Barron VA, Luo G, Lou H. 2006. A nuclear function of $\mathrm{Hu}$ proteins as neuron-specific alternative RNA processing regulators. Mol Biol Cell 17: 5105-5114.

Zhu H, Hinman MN, Hasman RA, Mehta P, Lou H. 2008. Regulation of neuron-specific alternative splicing of neurofibromatosis type 1 premRNA. Mol Cell Biol 28: 1240-1251. 

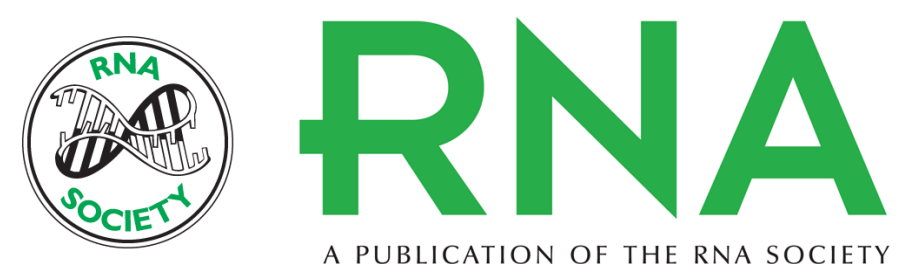

A PUBLICATION OF THE RNA SOCIETY

\section{Emerging complexity of the HuD/ELAVI4 gene; implications for neuronal development, function, and dysfunction}

Lucas M. Bronicki and Bernard J. Jasmin

RNA 2013 19: 1019-1037

References This article cites 218 articles, 90 of which can be accessed free at: http://rnajournal.cshlp.org/content/19/8/1019.full.html\#ref-list-1

Creative This article is distributed exclusively by the RNA Society for the first 12 months after the Commons full-issue publication date (see http://rnajournal.cshlp.org/site/misc/terms.xhtml). After 12 License months, it is available under a Creative Commons License (Attribution-NonCommercial 3.0 Unported), as described at http://creativecommons.org/licenses/by-nc/3.0/.

Email Alerting Receive free email alerts when new articles cite this article - sign up in the box at the Service top right corner of the article or click here. 